\title{
CARBON DIOXIDE, HYDROGRAPHIC, AND CHEMICAL DATA OBTAINED DURING THE R/V METEOR CRUISE 11/5 IN THE SOUTH ATLANTIC AND NORTHERN WEDDELL SEA AREAS (WOCE SECTIONS A-12 AND A-21)
}

\section{Contributed by}

David W. Chipman, Taro Takahashi, Dee Breger, and Stewart C. Sutherland

Lamont-Doherty Earth Observatory of Columbia University Palisades, N.Y. 10964

Prepared by A. Kozyr ${ }^{*}$ and A. F. Gaslightwala* Carbon Dioxide Information Analysis Center Oak Ridge National Laboratory Oak Ridge, Tennessee

"Energy, Environment, and Resources Center The University of Tennessee, Knoxville

** Summer intern from Cornell University Environmental Sciences Division Publication No. 4282

Date Published: July 1994

Prepared for the Global Change Research Program Environmental Sciences Division Office of Health and Environmental Research U.S. Department of Energy

Budget Activity Number KP 0500000

Prepared by the

Carbon Dioxide Information Analysis Center OAK RIDGE NATIONAL LABORATORY

Oak Ridge, Tennessee 37831-6335 managed by

MARTIN MARIETTA ENERGY SYSTEMS, INC. for the

U.S. DEPARTMENT OF ENERGY under contract DE-AC05-84OR21400 



\section{DISCLAIMER}

This report was prepared as an account of work sponsored by an agency of the United States Government. Neither the United States Government nor any agency thereof, nor any of their employees, make any warranty, express or implied, or assumes any legal liability or responsibility for the accuracy, completeness, or usefulness of any information, apparatus, product, or process disclosed, or represents that its use would not infringe privately owned rights. Reference herein to any specific commercial product, process, or service by trade name, trademark, manufacturer, or otherwise does not necessarily constitute or imply its endorsement, recommendation, or favoring by the United States Government or any agency thereof. The views and opinions of authors expressed herein do not necessarily state or reflect those of the United States Government or any agency thereof. 


\section{DISCLAIMER}

Portions of this document may be illegible in electronic image products. Images are produced from the best available original document. 


\section{CONTENTS}

Page

LIST OF FIGURES $\ldots \ldots \ldots \ldots \ldots \ldots \ldots \ldots \ldots \ldots \ldots \ldots \ldots \ldots \ldots$

LIST OF TABLES $\ldots \ldots \ldots \ldots \ldots \ldots \ldots \ldots \ldots \ldots \ldots \ldots \ldots \ldots \ldots$ vii

ABSTRACT $\ldots \ldots \ldots \ldots \ldots \ldots \ldots \ldots \ldots \ldots \ldots \ldots \ldots \ldots \ldots \ldots \ldots \ldots \ldots \ldots$

PART 1: OVERVIEW $\ldots \ldots \ldots \ldots \ldots \ldots \ldots \ldots \ldots \ldots \ldots \ldots \ldots \ldots \ldots$

1. BACKGROUND INFORMATION $\ldots \ldots \ldots \ldots \ldots \ldots \ldots \ldots \ldots \ldots \ldots$

2. DESCRIPTION OF THE EXPEDITION $\ldots \ldots \ldots \ldots \ldots \ldots \ldots \ldots \ldots \ldots \ldots$

2.1 R/V Meteor, Technical Details and History $\ldots \ldots \ldots \ldots \ldots \ldots \ldots \ldots$

$2.2 \mathrm{R} / \mathrm{V}$ Meteor Cruise $11 / 5$ Information $\ldots \ldots \ldots \ldots \ldots \ldots \ldots \ldots \ldots$

2.3 Brief Cruise Summary $\ldots \ldots \ldots \ldots \ldots \ldots \ldots \ldots \ldots \ldots \ldots \ldots$

3. DESCRIPTION OF VARIABLES $\ldots \ldots \ldots \ldots \ldots \ldots \ldots \ldots \ldots \ldots \ldots \ldots$

4. DATA CHECKS PERFORMED BY CDIAC $\ldots \ldots \ldots \ldots \ldots \ldots \ldots \ldots$

5. HOW TO OBTAIN THE DATA AND DOCUMENTATION $\ldots \ldots \ldots \ldots \ldots$

6. REFERENCES $\ldots \ldots \ldots \ldots \ldots \ldots \ldots \ldots \ldots \ldots \ldots \ldots \ldots \ldots \ldots \ldots$

PART 2: CONTENT AND FORMAT OF DATA FILES $\ldots \ldots \ldots \ldots \ldots \ldots \ldots \ldots$

7. FILE DESCRIPTIONS $\ldots \ldots \ldots \ldots \ldots \ldots \ldots \ldots \ldots \ldots \ldots \ldots \ldots \ldots \ldots$

readme $($ File 1) $\ldots \ldots \ldots \ldots \ldots \ldots \ldots \ldots \ldots \ldots \ldots \ldots \ldots \ldots \ldots \ldots \ldots$

stainv.for (File 2) $\ldots \ldots \ldots \ldots \ldots \ldots \ldots \ldots \ldots \ldots \ldots \ldots \ldots \ldots \ldots \ldots \ldots \ldots$

m115dat.for (File 3) $\ldots \ldots \ldots \ldots \ldots \ldots \ldots \ldots \ldots \ldots \ldots \ldots \ldots \ldots \ldots$

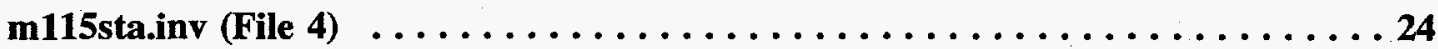

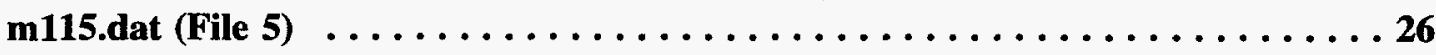


Page

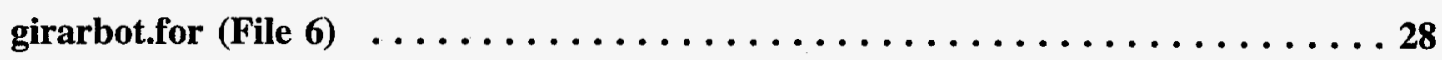

m115gir.dat (File 7) $\ldots \ldots \ldots \ldots \ldots \ldots \ldots \ldots \ldots \ldots \ldots \ldots \ldots \ldots$

8. VERIFICATION OF DATA TRANSPORT $\ldots \ldots \ldots \ldots \ldots \ldots \ldots \ldots \ldots$

APPENDIX A: STATION INVENTORY $\ldots \ldots \ldots \ldots \ldots \ldots \ldots \ldots \ldots \ldots \ldots$

APPENDIX B: SURFACE WATER DATA $\ldots \ldots \ldots \ldots \ldots \ldots \ldots \ldots \ldots$ 


\section{LIST OF FIGURES}

Figure

Page

1 Station locations during the R/V Meteor Cruise 11/5

2 Sampling depths at the 78 hydrographic stations occupied during the $\mathrm{R} / \mathrm{V}$ Meteor Cruise 11/5

3 Repeated measurements of the total $\mathrm{CO}_{2}$ concentration in sea surface (A) and in deep water (B) samples $\ldots \ldots \ldots \ldots \ldots \ldots \ldots \ldots \ldots \ldots \ldots$

4 Nested profiles: Total carbon $(\mu \mathrm{mol} / \mathrm{kg})$ vs pressure (dbar) for stations $102-141 \ldots 13$

5 Nested profiles: Total carbon $(\mu \mathrm{mol} / \mathrm{kg}$ ) vs pressure (dbar) for stations $142-179 \ldots 14$

6 Property-property plots for all stations occupied during the R/V Meteor

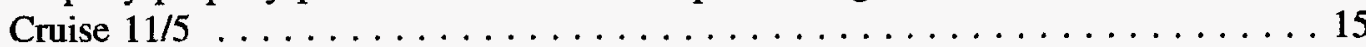




\section{LIST OF TABLES}

Table

Page

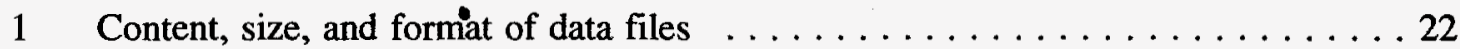

2 Partial listing of "m115sta.inv" (File 4) $\ldots \ldots \ldots \ldots \ldots \ldots \ldots \ldots \ldots \ldots \ldots \ldots \ldots$

3 Partial listing of "m115.dat" (File 5) $\ldots \ldots \ldots \ldots \ldots \ldots \ldots \ldots \ldots \ldots \ldots$

4 Partial listing of "m115gir.dat" (File 7$) \ldots \ldots \ldots \ldots \ldots \ldots \ldots \ldots$

A.1 Station inventory information for the 78 sites occupied during the

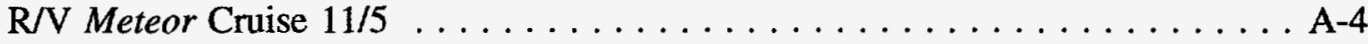

B.1 Surface water data obtained during the $\mathrm{R} / \mathrm{V}$ Meteor Cruise $11 / 5 \ldots \ldots \ldots$ B-4 



\begin{abstract}
Chipman, D. W., T. Takahashi, D. Breger, and S. C. Sutherland. 1994. Carbon Dioxide, Hydrographic, and Chemical Data Obtained During the R/V Meteor Cruise 11/5 in the South Atlantic and Northern Weddell Sea Areas (WOCE sections A-12 and A-21). ORNL/CDIAC-55, NDP-045. Carbon Dioxide Information Analysis Center, Oak Ridge National Laboratory, Oak Ridge, Tennessee. 56 pp.
\end{abstract}

This document presents the procedures and methods used to obtain carbon dioxide $\left(\mathrm{CO}_{2}\right)$, hydrographic, and chemical data during the R/V Meteor Expedition 11/5 in the South Atlantic Ocean, including the Drake Passage (Section A-12); the Northern Weddell Sea; and the Eastern South Atlantic Ocean (Section A-21). This cruise was conducted as part of the World Ocean Circulation Experiment (WOCE).

The cruise started from Ushuaia, Argentina, on January 23, 1990, and ended at Capetown, South Africa on March 8, 1990. Samples were collected at 78 stations that covered the Drake Passage $\left(56-63^{\circ} \mathrm{S}\right)$; the Northern Weddell Sea $\left(45-35^{\circ} \mathrm{W}\right)$; a section along the $58^{\circ} \mathrm{W}$ parallel $\left(25^{\circ} \mathrm{W}\right.$-prime meridian); and two segmented S-N sections between the Northern Weddell Sea and Capetown, South Africa. Measurements taken at WOCE sections A-12 and A-21 included pressure, temperature, salinity measured by the Conductivity, Temperature and Depth sensor (CTD); bottle salinity; oxygen; phosphate; nitrate; nitrite; silicate; total carbon concentration $\left(\mathrm{TCO}_{2}\right)$; and partial pressure of $\mathrm{CO}_{2}\left(\mathrm{pCO}_{2}\right)$ measured at $20^{\circ} \mathrm{C}$. In addition, potential density at 0 decibar (dbar) and potential temperature were calculated from the measured variables.

The $\mathrm{TCO}_{2}$ concentration in seawater samples was measured using a coulometer with an estimated precision of approximately $\pm 1 \mu \mathrm{mol} / \mathrm{kg}$. The coulometer was calibrated frequently at sea by using a high-precision gas pipette and $\mathrm{CO}_{2}$ gas (99.998\%). The $\mathrm{pCO}_{2}$ value in seawater samples was measured at $20^{\circ} \mathrm{C}$ by means of a constant volume ( $500 \mathrm{ml}$ seawater) equilibrator and a gas chromatograph. $\mathrm{CO}_{2}$ in equilibrated gas was first converted to methane, by using a ruthenium catalyst, and then measured by a flame-ionization detector. The precision of $\mathrm{pCO}_{2}$ measurements has been estimated to be approximately $\pm 0.1 \%$.

The $\mathrm{CO}_{2}$ investigation during the $\mathrm{R} / \mathrm{V}$ Meteor Cruise $11 / 5$ was supported by a grant from the U.S. Department of Energy (No. DE-FGO2-90ER60943).

The data set is available, free of charge, as a Numeric Data Package (NDP) from CDIAC. The NDP consists of seven data files and this printed documentation, which describes the contents and format of all data files as well as the procedures and methods used to obtain these data during the R/V Meteor Cruise 11/5.

Keywords: Carbon dioxide; World Ocean Circulation Experiment (WOCE); South Atlantic Ocean; Weddell Sea; hydrographic measurements; carbon cycle. 
PART 1:

OVERVIEW 



\section{BACKGROUND INFORMATION}

The World Ocean plays a dynamic role in the Earth's climate: it captures heat from the sun, transports it, and releases it thousands of miles away. These oceanic-solar-atmospheric interactions affect winds, rainfall patterns, and temperatures on a global scale. The oceans also play a major role in global carbon cycle processes. Carbon in the oceans is unevenly distributed because of complex circulation patterns and biogeochemical cycles, neither of which is completely understood. In addition to circulation patterns, biological processes (i.e., photosynthesis and respiration) play a crucial role in the carbon cycle. The oceans are estimated to hold 38,000 gigatons of carbon, which is $\mathbf{5 0}$ times more carbon than that in the atmosphere and 20 times more carbon than that held by plants, animals, and the soil (Williams 1990). Thus, if only $2 \%$ of the carbon stored in the oceans is released, the level of atmospheric carbon dioxide $\left(\mathrm{CO}_{2}\right)$ would double (Williams 1990). Furthermore, every year more than 15 times as much $\mathrm{CO}_{2}$ is exchanged across the sea surface than the amount produced by the burning of fossil fuels, deforestation, and other human activities (Williams 1990).

Several large experiments were conducted in the past, and others are currently under way, attempting to better understand the oceans and their role in climate and the global carbon cycle. One of the earliest large-scale oceanographic projects was the Geochemical Ocean Section Study (GEOSECS). The goal of GEOSECS was to study geochemical properties of the oceans with respect to large-scale circulation problems. The project, which covered the Atlantic (1972-73), Pacific (1973-74), and Indian (1977-78) oceans, officially started in 1971 and was noted for its use of equipment and techniques that were at the forefront of modern technology and knowledge. The Transient Tracers in the Ocean (TTO) project (1982) was designed to measure the distribution of $\mathrm{CO}_{2}$ and hydrographic properties in the North Atlantic Ocean. The World Ocean Circulation Experiment (WOCE) started in 1990 and is currently under way. WOCE is the first research program of sufficient scope to mount a true global study of the ocean. WOCE brings together the expertise of scientists and technicians from many nations in an oceanographic experiment that is larger than any ever attempted. Another multinational program currently under way is the Joint Global Ocean Flux Study (JGOFS). The purpose of JGOFS is to investigate the processes controlling marine biogeochemical cycles, specifically carbon and nutrient cycles.

During the lifetime of the WOCE project, from 1990 to 1997, approximately 23,000 stations will be sampled in oceans around the world. This document provides and describes data collected during a 45-day expedition in the South Atlantic Ocean, Northern Weddell Sea, and Drake Passage aboard the German research vessel Meteor. The cruise, referred to as cruise number 11 , leg $5(11 / 5)$, was conducted during the austral summer. It started at Ushuaia, Argentina, on January 23, 1990, and ended at Capetown, South Africa, on March 8, 1990 . Seventy-eight stations were occupied along the WOCE sections A-21 and A-12 (Fig. 1).

The $\mathrm{CO}_{2}$ investigation during the $\mathrm{R} / \mathrm{V}$ Meteor Cruise $11 / 5$ was supported by a grant from the U.S. Department of Energy (DOE) No. DE-FGO2-90ER60943.

\section{DESCRIPTION OF THE EXPEDITION}

\subsection{R/V Meteor, Technical Details and History}

The research vessel Meteor is owned by the Federal Republic of Germany and is operated by the Federal Ministry for Research and Technology. The basic features of the vessel are described below. 


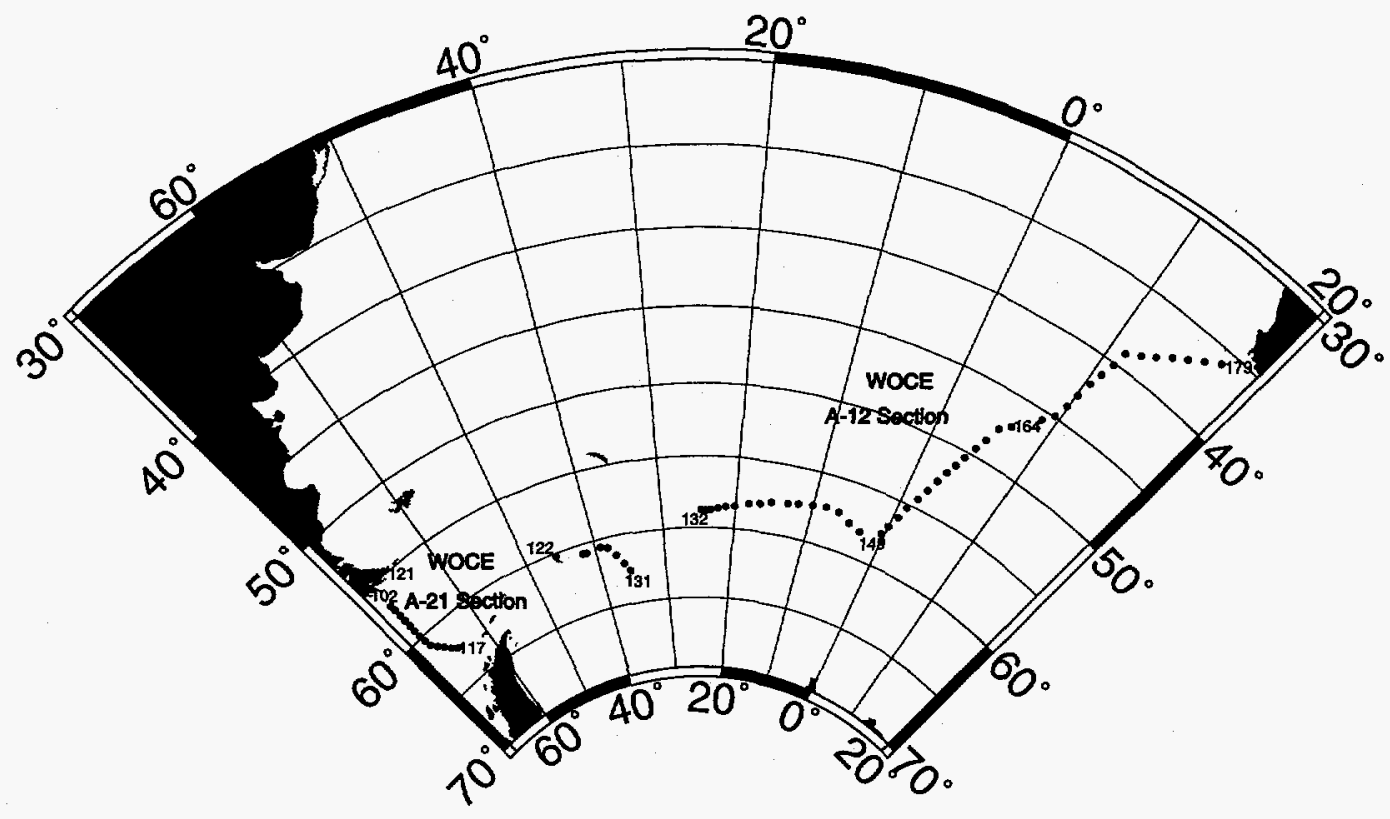

Figure 1. Station locations during the R/V Meteor Cruise 11/5.

Port of registration:

Call sign:

Classification:

Operator:

Built:

Basic dimensions:

\section{Personnel:}

Main engine:

Propulsion:

Fuel consumption:

Maximum cruise duration:

Nautical equipment:

Science quarters:
Hamburg

DBBH

GL+100A4E2+MC Auto

University of Hamburg, Institute for Ocean Research 1985-86 at Schlichting Werft, Travemunde

GRT: 3990, NRT 1284; Displacement: 4780t; Length o.a.: $97.50 \mathrm{~m}$; Beam: $16.50 \mathrm{~m}$; Draught: $\max .5 .60 \mathrm{~m}$; Service speed: $12 \mathrm{kn}$; Depth main deck: $7.70 \mathrm{~m}$

Crew: 32 ; Scientists: 30

$4 \times$ Mak6M $322=4 \times 1,000 \mathrm{~kW}$ at $750 \mathrm{rpm}$

Diesel-electrical, Tandem-Motor $=2 \times 1,150 \mathrm{~kW}$

approximately $12.0 \mathrm{t}$ IFO 80 per day at service speed 60 days

Integrated navigation system with data transfer to position computer, echosounder sýnchronization and supervision, data-processing facility

20 laboratories on the main deck with approximately 400 $\mathrm{m}^{2}$ of working space for multidisciplinary research 
The original Meteor (I) was constructed in 1925; it was the first research and survey vessel of that name. R/V Meteor was owned by the German navy and was based in Wilhelmshaven. One of the Meteor's first expeditions was the German Atlantic Ocean Expedition of 1925-27, which was organized by the Institute of Marine Research in Berlin. Thereafter, the vessel was used for German physical, chemical, and microbiological marine investigations and for navy surveying and fisheries protection duties.

The Meteor (II) was planned since the end of the 1950s and was operated by the Deutsche Forschungsgemeinschaft (German Science Community) in Bad Godesberg and the Deutsches Hydrographisches Institut (German Hydrographic Institute) in Hamburg. Meteor (II) was commissioned in 1964 and participated in the International Indian Ocean Expedition.

It was replaced by the newly built, multipurpose vessel Meteor (III), which was completed in 1986. The Hamburg-based Meteor (III) is used for German ocean research worldwide and for cooperative efforts with other nations in this field. The vessel serves scientists of all marine disciplines in all of the world's oceans.

\subsection{R/V Meteor Cruise 11/5 Information}

The following is the cruise information:

\begin{tabular}{|c|c|}
\hline Ship Name: & Meteor \\
\hline Cruise/Leg: & $11 / 5$ \\
\hline Location: & Ushuaia, Argentina, to Cape Town, South Africa \\
\hline Dates: & January 23-March 8, 1990 \\
\hline Funding: & German Science Community \\
\hline & Federal Ministry of Research and Technology, Bonn, Germany \\
\hline Chief Sc & $\begin{array}{l}\text { Dr. Wolfgang Roether } \\
\text { University of Bremen, Germany }\end{array}$ \\
\hline
\end{tabular}

Parameters measured, institution, and responsible Principal Investigators (PI):

Parameter

CTD, Salinity

Nutrients, Oxygen

CFM's

Tritium, ${ }^{3} \mathrm{He}$

${ }^{14} \mathrm{C}$ (L-V and AMS)

${ }^{39} \mathrm{Ar}$

${ }^{85} \mathrm{Kr}$

$\mathrm{TCO}_{2}$ and $\mathrm{pCO}_{2}$ ${ }^{226 / 228} \mathrm{Ra}$

XBT

ADCP

CTD-intercomparison

ALACE Drifter
Institution

Alfred Wegner Institute, Bremerhaven

Scripps Institution of Oceanography (SIO)

University of Bremen

University of Bremen

University of Heidelberg

University of Bern

Lamont-Doherty Earth Observatory

Lamont-Doherty Earth Observatory

Princeton University, Univ. of Kiel

Alfred Wegner Institute, Bremerhaven

Alfred Wegner Institute, Bremerhaven

AWI, SIO

SIO, Texas A\&M University
PI

G. Rohardt, E. Fahrbach

J. Swift, F. Delahoyde

W. Roether

W. Roether

P. Schlosser, K. O. Munnich

H. H. Loosli

W. M. Smethie

D. Chipman, T. Takahashi

R. Key, M. Rhein

U. Schauer, E. Farhrbach

E. Farhrbach

G. Rohardt, F. Delahoyde

R. Davis, W. D. Nowlin 


\subsection{Brief cruise summary}

The R/V Meteor left Ushuaia on the morning of January 23, 1990. The next morning, sampling started southwest of Cape Horn and continued south-ward at 30-nm station spacing. Basic equipment included a Neil Brown Mark IIIB CTD (AWI, calibrated at SIO Oceanographic Data Facility) and a $24 \times 12$ liter General Oceanic rosette system. Large-volume stations were placed between the fronts in order to characterize the four principle hydrographic zones of the passage (Sievers and Nowlin 1984). Apart from $\mathrm{pCO}_{2}$, which became operative only toward the end of the section, all measurements were carried out successfully. Measurements of salinity, oxygen, and nutrients (nitrate, nitrite, silicate, and phosphate) were made in the standard fashion. The weather was advantageous for all of the Drake Passage section work.

After 3 days of station work, the winch computer system malfunctioned. The ship crew managed to provide makeshift operation for the CTD/Rosette winch, and the trawl winch operation for large-volume sampling was similarly resumed 2 days later. It was decided to continue the section and then return to Ushuaia for repairs. The section was concluded after sampling near the South Shetland Arc shelf off Smith Island. During the section, 13 standard and 4 large-volume stations were occupied. However, the large-volume samples in the Polar Frontal Zone were collected on the way back to Ushuaia (i.e. not simultaneously with the corresponding main $\mathrm{CTD} /$ Rosette work). In total, at least 4 days were lost as a result of the winch malfunction.

After the vessel left Ushuaia (February 3,1990) the second time, station work resumed on February 6; 1990, with a short section north and east of the South Orkney Islands (Stations 122-131).

On February 12, 1990, after rounding Southern Thule of the South Sandwich Islands, sampling began on WOCE section A-12 (stations 132-179), and continued up to the African shelf until the morning of March 8, 1990, when R/V METEOR entered Ċape Town.

A historic comment: From January 21 to March 10, 1926, the original Meteor (I) also explored a transect from Ushuaia to Cape Town, which was leg 5 of its famous South Atlantic survey. The scientific topic, i.e. hydrography, was quite similar. A total of 34 stations were sampled (6 across Drake Passage), 3 properties were measured (temperature, salinity, and oxygen), and 26 depths typically were sampled (in 3 casts) (Roether et al. 1990). 


\section{DESCRIPTION OF VARIABLES}

Data file m115.dat (see description on pp. 26-28) in this numeric data package contains the following variables: station numbers; cast numbers; sample numbers; bottle numbers; CTD pressures; CTD temperatures; CTD salinities; potential temperatures; bottle salinities; concentrations of dissolved oxygen, silicate, nitrate, nitrite, phosphate; total $\mathrm{CO}_{2}$ concentrations; partial pressures of $\mathrm{CO}_{2}$ at $20^{\circ} \mathrm{C}$; potential densities at $0 \mathrm{dbar}$; and quality flags. Station inventory file m115sta.inv (pp. 24-25) contains section numbers; station numbers; latitude, longitude, sampling date (i.e., day, month, and year), and bottom depth for each station.

In accordance with WOCE data management policies, which stipulate that WOCE data are not final until designated as such by the chief scientist, we have rounded the CTD salinity, CTD temperature, potential temperature, and density values to two decimal places. If the chief scientist designates these parameters as final, these variables will be restored to their original precision.

The temperature and pressure readings of the Neil Brown IIIB CTD unit were corrected through the use of 4-6 pairs of reversing thermometers; the electrical conductivity readings were corrected by using the salinity values determined aboard the ship for all 24 Niskin samplers. A Guildline ${ }^{\circledR}$ Autosal 8400 A salinometer and the Wormley Salinity Standards were used for the determination of salinity in the discrete water samples. The precision of the measurements obtained by the CTD unit has been estimated to be $\pm 0.002^{\circ} \mathrm{C}$ for temperature and $\pm 0.002^{\circ}$ for salinity. Potential temperature $(\Theta)$ and potential density $\left(\sigma_{0}\right)$ values were computed through the use of the potential temperature algorithm of Fofonoff (1980), the International Equation of State for Seawater (Millero et al. 1980), and Bryden's (1973) formulation for the adiabatic temperature gradient.

The concentration of dissolved oxygen was determined by means of the Winkler titration method. A molar volume at STP of 22.385 liter/mole (Kester 1975) was used to convert oxygen concentrations from milliliter per liter to micromoles per kilogram of seawater at the in situ temperature.

The concentrations of nitrate, nitrite, phosphate, and silicate dissolved in the seawater samples were determined through the use of standard calorimetric methods with an Auto-Analyzer. Determinations were generally made within 6 hours of collection. The water samples were stored in a refrigerator at $4^{\circ} \mathrm{C}$ before analysis.

All of the concentration values are expressed in units of per kilogram of seawater, although analytical samples were isolated by volumetric means. For the conversion from the volume to the mass of seawater sample, the density of each water sample was computed by using the International Equation of State for Seawater (Millero et al. 1980) and the measured salinity and the temperature at which the volumetric measurements were made.

The total $\mathrm{CO}_{2}$ concentration in approximately 1300 seawater samples and the $\mathrm{CO}_{2}$ partial pressure in approximately 870 seawater samples collected at 76 stations (Fig. 2) were determined aboard the ship. The $\mathrm{TCO}_{2}$ concentration in seawater samples was determined by the use of a coulometric system, which was modified from that described by Johnson et al. (1985). 


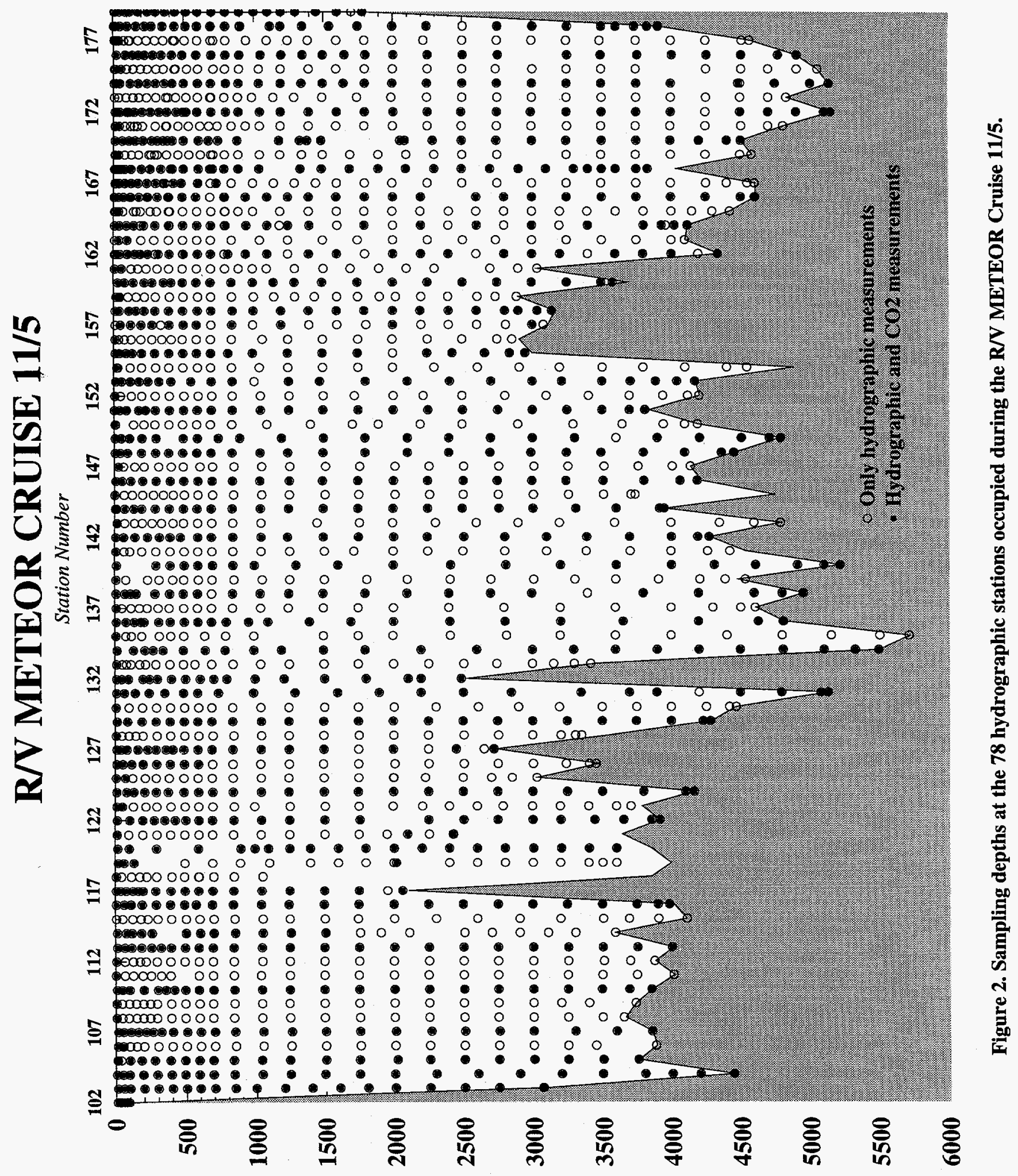

(ui) $41 d \partial a$ 
For analysis, the seawater was introduced into the stripping chamber using fixed-volume syringes. The sample was acidified with $1 \mathrm{ml}$ of $8.5 \%$ phosphoric acid while it was in the stripping chamber, where the evolved $\mathrm{CO}_{2}$ gas was swept from the sample and transferred with a stream of $\mathrm{CO}_{2}$-free air into the electrochemical cell of the $\mathrm{CO}_{2}$ coulometer (UTC-Coulometric Model-5011). In the coulometer cell, the $\mathrm{CO}_{2}$ was quantitatively absorbed by a solution of ethanolamine in dimethylsulfoxide (DMSO). Reaction between the $\mathrm{CO}_{2}$ and the ethanolamine formed the weak hydroxyethylcarbamic acid. The $\mathrm{pH}$ change of the solution associated with the formation of the acid resulted in a color change of the thymophthalein $\mathrm{pH}$ indicator in the solution. The color change, from deep blue to colorless, was detected by a photodiode, which continually monitored the transmissivity of the solution. The electronic circuitry of the coulometer, on detecting the change in the color of the $\mathrm{pH}$ indicator, caused a current to be passed through the cell generating hydroxyl $\left(\mathrm{OH}^{-}\right)$ions from a small amount of water in the solution. The $\mathrm{OH}^{-}$that was generated titrated the acid, returning the solution to its original $\mathrm{pH}$ (and hence color); the circuitry then interrupted the current flow. The product of current passed through the cell and time was related by the Faraday constant to the number of moles of $\mathrm{OH}^{-}$generated to titrate the acid and hence to the number of moles of $\mathrm{CO}_{2}$ absorbed to form the acid.

The volumes delivered by the constant-volume syringes were determined by repeatedly weighing distilled water dispensed in the same manner as a sample; the volume was calculated from the delivered weight by using the density of pure water at the temperature of the measurement and a buoyancy correction for the air displaced by the water (amounts to approximately $0.1 \%$ of the weight of the water). The density of the seawater in the pipet was calculated at the temperature of injection by using the International Equation of State (Millero et al. 1980).

The coulometer was calibrated by introducing research-grade $\mathrm{CO}_{2}$ gas $(99.998 \%)$ into the carrier gas line upstream of the extraction tube, using a pair of fixed-volume sample loops on a gas-sampling valve and measuring the gas pressure in the loops as the gas was vented to the ambient atmosphere, and determining the barometric pressure by means of the electronic barometer used with the $\mathrm{pCO}_{2}$ system. The loop temperature was measured to $\pm 0.05^{\circ} \mathrm{C}$ with a thermometer calibrated against one traceable to the National Institute of Standards and Technology (NIST), and the non-ideality of $\mathrm{CO}_{2}$ was incorporated in the computation of the loop contents. The volume of the calibration loop had previously been determined by weighing empty loops and then loops filled with mercury. The volumes of these loops have additionally been checked by comparing the amount of $\mathrm{CO}_{2}$ introduced by them with the amount derived from gravimetric samples of calcium carbonate and sodium carbonate. They were found to be accurate to within $0.1 \%$. During the expedition, the coulometer was calibrated several times daily by using the calibrated loop and pure $\mathrm{CO}_{2}$ gas.

In order to evaluate the long-term reproducibility and precision of the coulometric determination of $\mathrm{CO}_{2}$ in seawater, a number of sample bottles were filled with a homogeneous sample of surface water and deep water. Bottles made of Pyrex glass and PET plastic $(500 \mathrm{ml}$ and $1000 \mathrm{ml}$, respectively) were used. Bottled samples were poisoned with mercuric chloride solutions ( $200 \mu \mathrm{l}$ for each $500-\mathrm{ml}$ water sample) and analyzed for total $\mathrm{CO}_{2}$ during the expedition. On the basis of these measurements (Fig. 3), the precision of $\mathrm{TCO}_{2}$ measurements during this expedition was estimated to be approximately $\pm 1 \mu \mathrm{mol} / \mathrm{kg}$. Additional details on the $\mathrm{TCO}_{2}$ measurements are discussed in Chipman et al. (1992).

A fully automated equilibrator-gas chromatograph system was used during the expedition to determined the $\mathrm{pCO}_{2}$ exerted by the seawater samples. Prior to analysis, the sample flasks were brought to $20^{\circ} \mathrm{C}$ in the thermostated water bath, and approximately $45 \mathrm{ml}$ of seawater was 


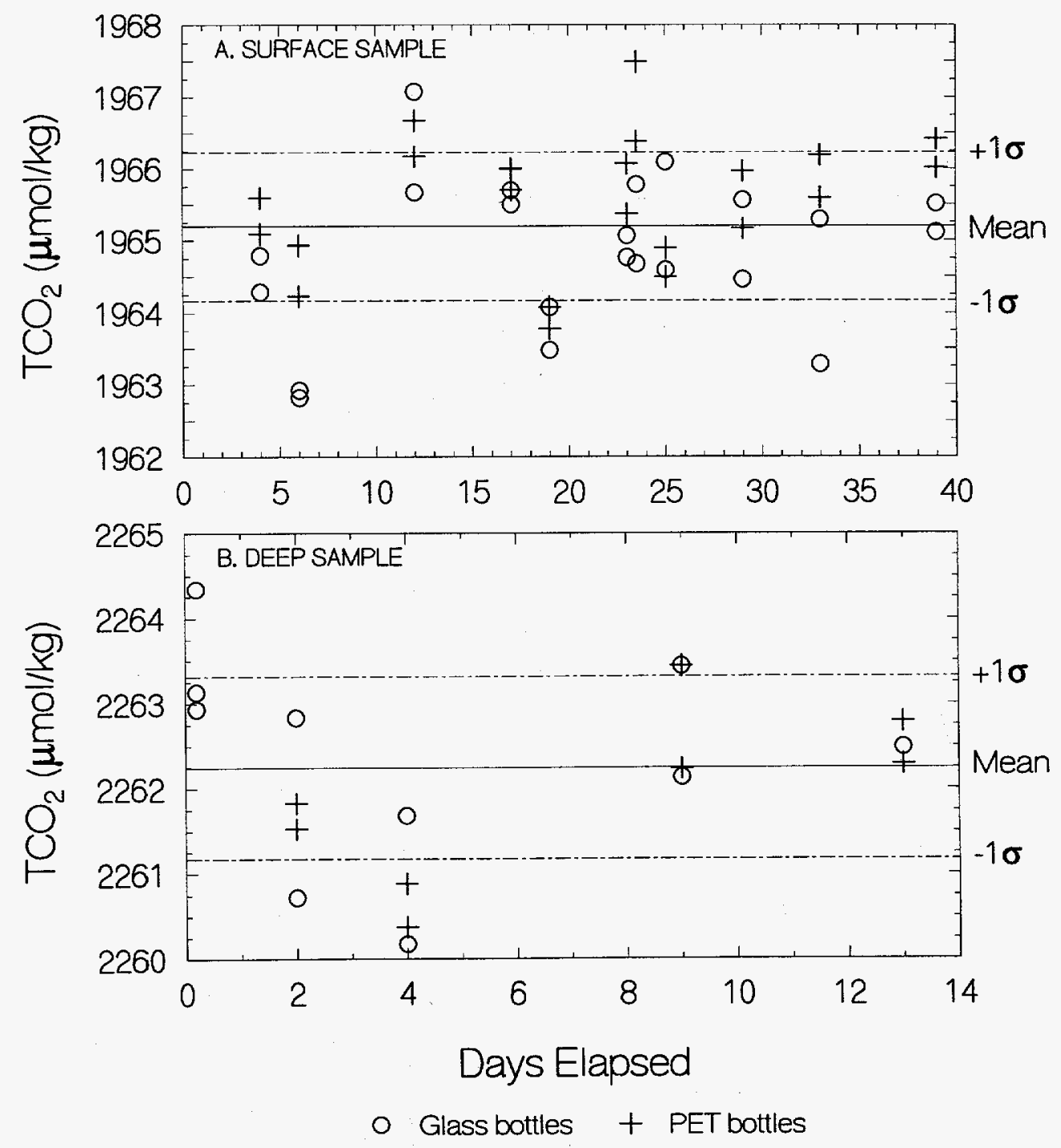

Figure 3. Repeated measurements of the total $\mathrm{CO}_{2}$ concentration in sea surface (A) and in deep water (B) samples. About 50 sample bottles were analyzed over a 50-day period during the expedition. Only 20 bottles were filled with a homogenized deep water sample and analyzed subsequently over a period of 13 days. The analyses of these samples yield a mean value of $1965.2 \pm 1.0$ for the surface samples and $2262.2 \pm 1.0$ for the deep water samples.

displaced with air that had a known $\mathrm{CO}_{2}$ concentration. The air in the flasks and in the tubing connecting the flasks to the sample loop of the gas chromatograph was recirculated continuously for approximately 20 minutes; the gas disperser about $1 \mathrm{~cm}$ below the water surface provided a large contact area between the water and air bubbles. At the end of the equilibration period, the circulation pump was switched off, and the air pressure throughout the system was allowed to equalize. A 1-ml aliquot of the equilibrated air was isolated from the equilibration subsystem and injected into the carrier gas stream of the gas chromatograph by cycling the gas sampling valve to which the sample loop was attached. After chromatographic separation, the $\mathrm{CO}_{2}$ was converted into methane and water vapor through a reaction with the hydrogen carrier in the catalytic 
converter. The methane produced by this reaction was then measured with a precision of $\pm 0.05 \%$ (one standard deviation) by the flame ionization detector. The concentration of $\mathrm{CO}_{2}$ in the sample was determined through comparison with the peak areas of known amounts of $\mathrm{CO}_{2}$ from injections of three reference gas mixtures, which were calibrated against the World Meteorological Organization standards created by C. D. Keeling. The reference gas mixtures were injected into the gas chromatograph by means of the same sample loop used for the equilibrated air samples; the pressure of the gas in the sample loop at the time of injection was determined by venting the loop to atmospheric pressure and measuring that pressure by means of a high-accuracy electronic barometer (Setra Systems, Inc., Model 270, accuracy \pm 0.3 millibar; calibration traceable to the NIST provided by the manufacturer). The sample loop was located within the well-controlled temperature environment of the column oven of the gas chromatograph; hence, all injections were made at a constant temperature.

The equilibrated air samples were saturated with water vapor at the temperature of equilibration and had the same $\mathrm{pCO}_{2}$ as the water sample. By injecting the air aliquot without removing the water vapor, the partial pressure of $\mathrm{CO}_{2}$ was determined directly, without the need to know the water vapor pressure (Takahashi et al. 1982). However, was necessary to know the pressure of equilibration, which was controlled by keeping the equilibrator flask at atmospheric pressure. The atmospheric pressure was, in turn, measured with the electronic barometer at the time each equilibrated air sample was injected into the gas chromatograph. Corrections were required to account for the change in $\mathrm{pCO}_{2}$ of the sample water as a result of the transfer of $\mathrm{CO}_{2}$ to or from the water during equilibration with the recirculating air. The overall precision of the $\mathrm{pCO}_{2}$ measurement is estimated to be about $\pm 0.10 \%$, based on the reproducibility of replicate equilibrations. Greater details on the $\mathrm{pCO}_{2}$ measurements are discussed in Chipman et al. (1992). 


\section{DATA CHECKS PERFORMED BY CDIAC}

An important part of the numeric data package (NDP) process at the Carbon Dioxide Information Analysis Center (CDIAC) involves the quality assurance (QA) of data before distribution. Data received at CDIAC are rarely in a condition that would permit immediate distribution, regardless of the source. To guarantee data of the highest possible quality, CDIAC conducts extensive QA reviews. Reviews involve examining the data for completeness, reasonableness, and accuracy. Although they have common objectives, these reviews are tailored to each data set, often requiring extensive programming efforts. In short, the QA process is a critical component in the value-added concept of supplying accurate, usable data for researchers.

The following summarizes the checks performed by CDIAC on the data obtained during the $\mathrm{R} / \mathrm{V}$ Meteor 11/5 Expedition in the South Atlantic Ocean and Northern Weddell Sea areas.

1. These data were provided to CDIAC in three files: $\mathrm{CO}_{2}$ measurements, along with downgraded hydrographic and chemical data, provided by Taro Takahashi and David Chipman from Lamont-Doherty Earth Observatory; hydrographic and chemical measurements, and station information files provided by the WOCE Hydrographic Program Office (WHPO) after quality evaluation; FORTRAN 77 retrieval code written and used to merge and reformat the first two data files.

2. All data were plotted by using a PLOTNEST.C program written by Stewart C. Sutherland (LDEO) to check for obvious outliers. The program plots a series of nested profiles, using the station number as an offset; the first station is defined at the beginning, and subsequent stations are offset by a fixed interval (Figs. 4 and 5). Some outliers were identified and removed after consultation with the principal investigators.

3. Property-property plots for all parameters were generated (Fig. 6), carefully examined, and compared with plots from previous expeditions in the South Atlantic Ocean to identify "noisy"data and possible systematic, methodological errors.

4. All variables were checked for values exceeding physical limits, such as sampling depth values that are greater than the given bottom depths.

5. Station locations (latitudes and longitudes) and sampling times were examined for consistency with maps and with cruise information supplied by Chipman et al. (1992).

6. CTD salinity, CTD temperature, potential temperature, and density have been downgraded to two decimal places in accordance with WOCE data management policies, which stipulate that data are not final until designated as such by the chief scientist. If the chief scientist designates these parameters as final, these values will be restored to their original precision.

7. The designation for missing values, given as -9.0 in the original files, was changed to -999.9 . 
R/V METEOR Cruise 11/5. South Atlantic Ocean.

Only profiles which exist in this Pressure (dbar) range are plotted. plotted parameter ranges from 1900 to 2300 .

$\bar{\omega}$

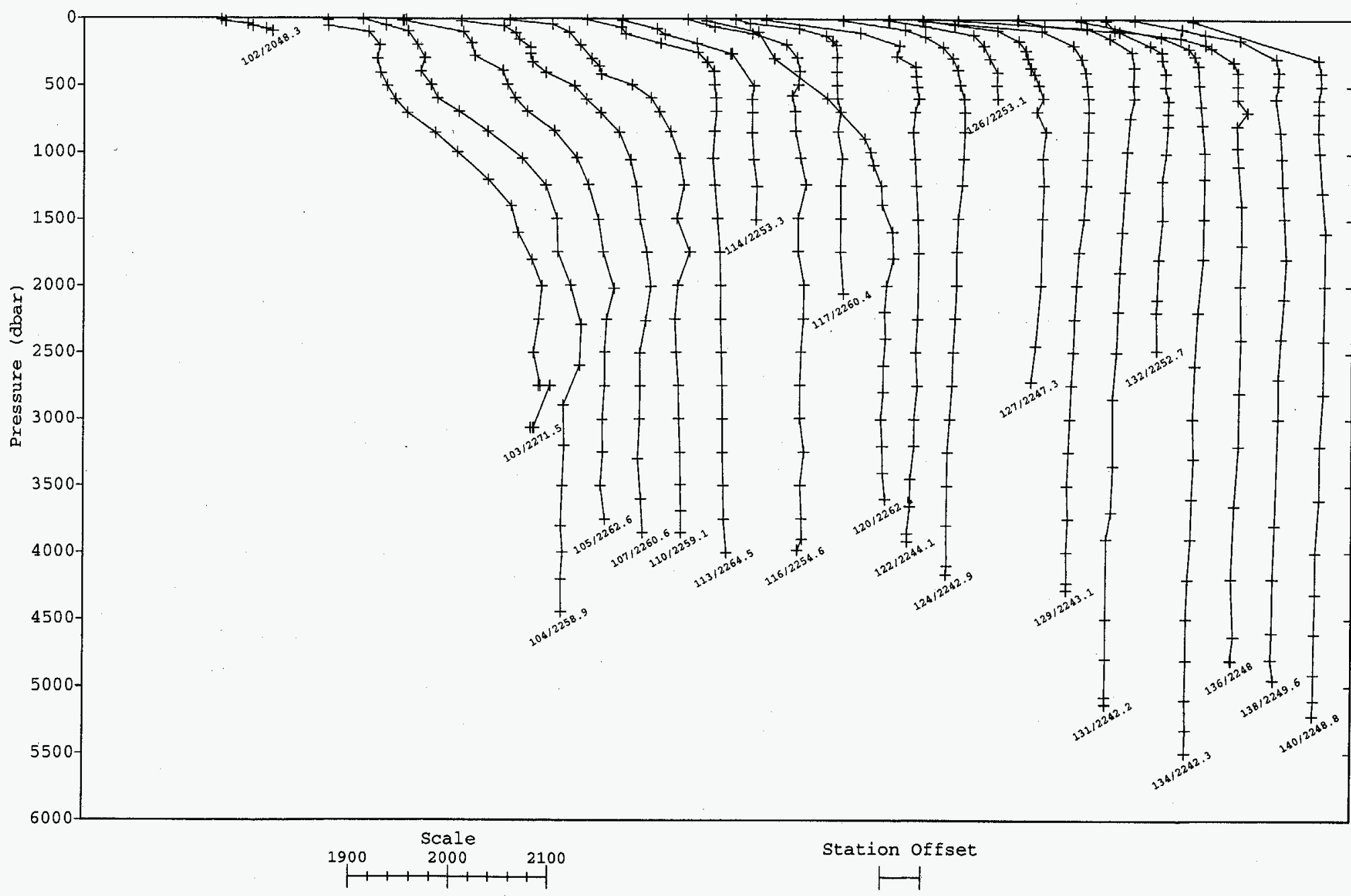

Figure 4. Nested profiles: Total carbon ( $\mu \mathrm{mol} / \mathrm{kg}$ ) vs pressure (dbar) for stations 102-141. 


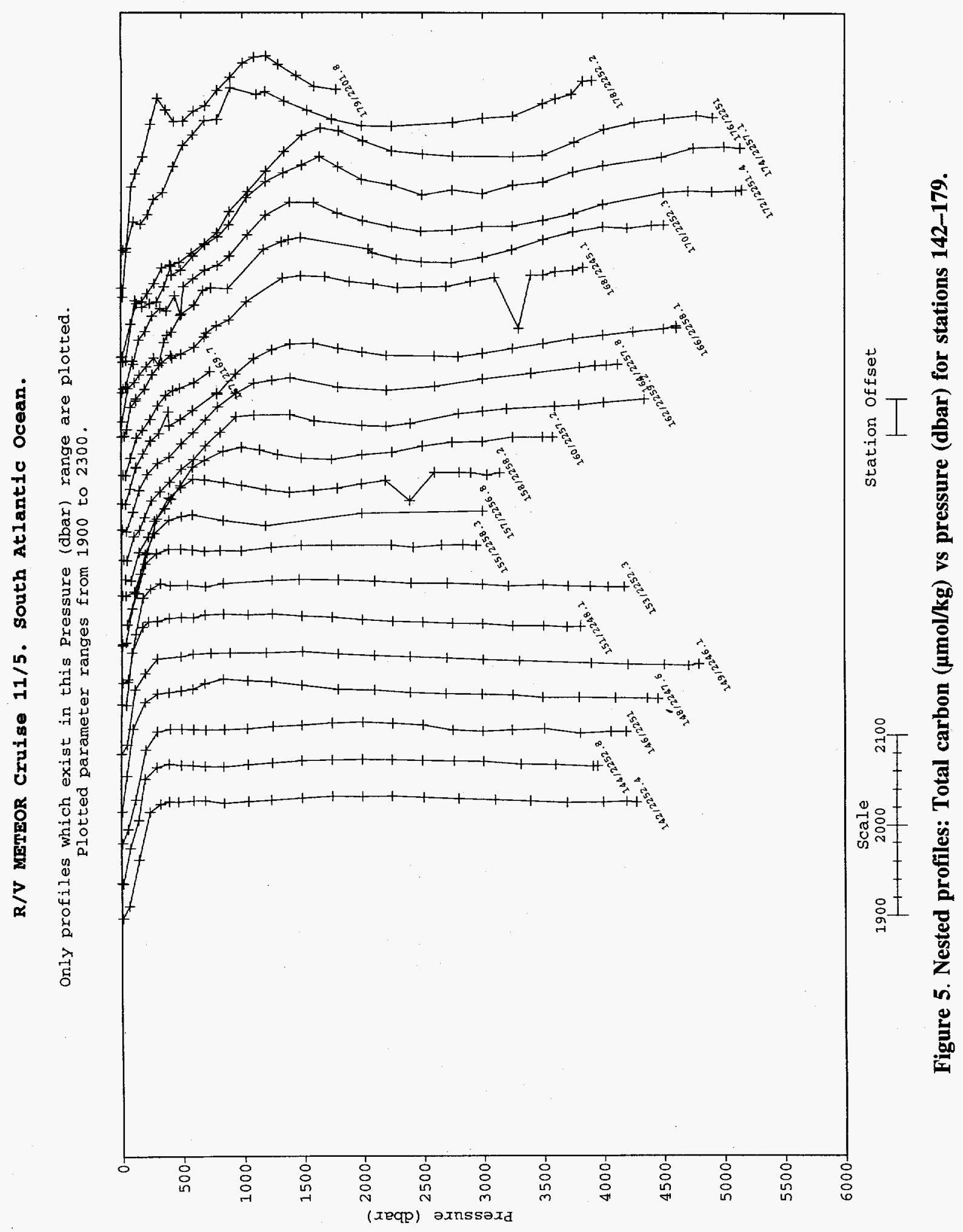



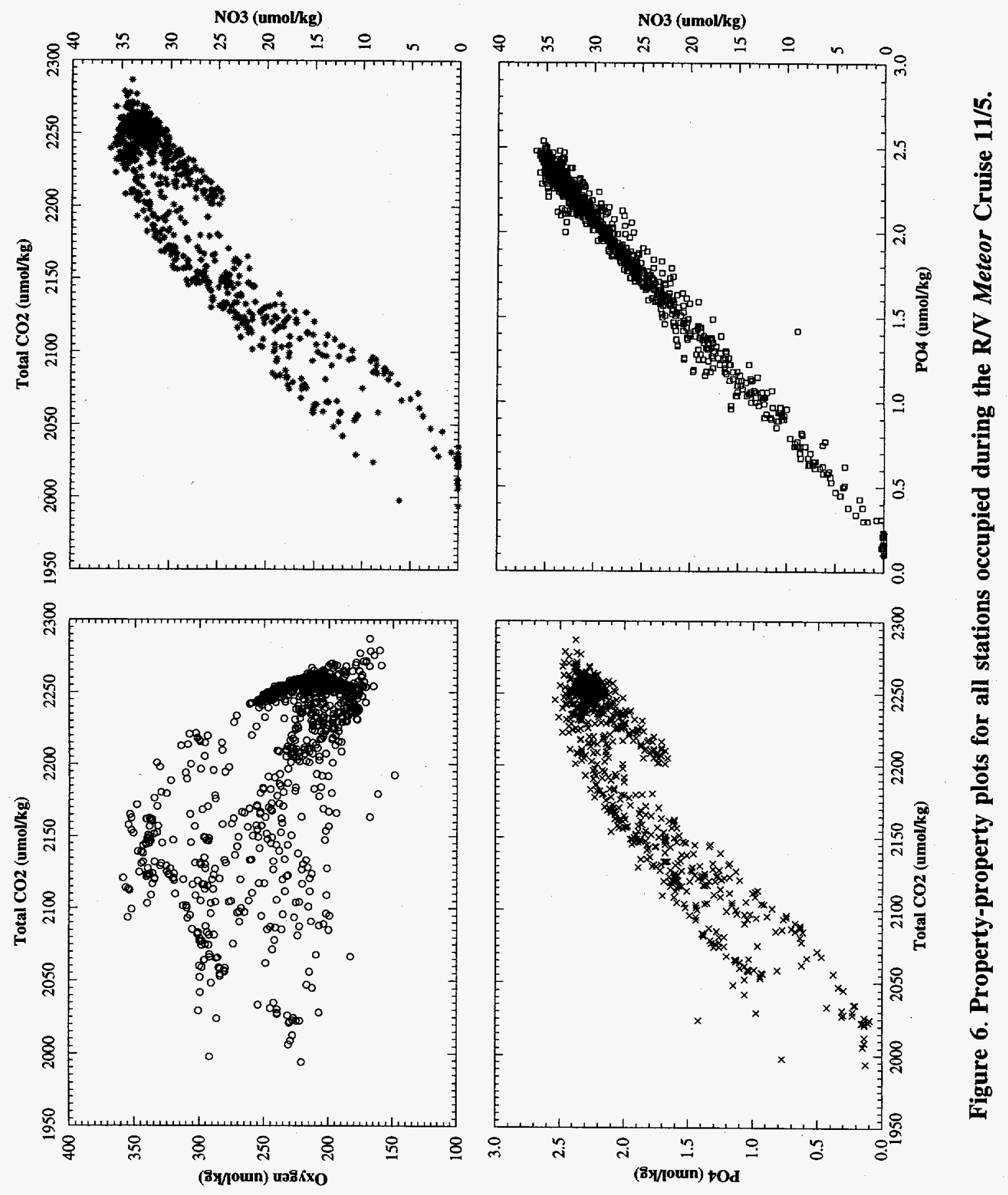


\section{HOW TO OBTAIN THE DATA AND DOCUMENTATION}

This data base is available in machine-readable form, on request, from CDIAC free of charge. CDIAC will also distribute subsets of the data base as needed. It can be acquired on 9-track magnetic tape; 8-mm tape; 150-mB, quarter-inch tape cartridge; IBM-formatted floppy diskettes; or from CDIAC's anonymous File Transfer Protocol (FTP) area via Internet (see FTP address below). Requests should include any specific media instructions (i.e., 1600 or $6250 \mathrm{BPI}$, labeled or nonlabeled, ASCII or EBCDIC characters, and variable- or fixed-length records; 3.5- or 5.25inch floppy diskettes, high or low density; 8200 or 8500 format, $8-\mathrm{mm}$ tape) required by the user to access the data. Magnetic tape requests not accompanied by specific instructions will be filled on 9-track, $6250 \mathrm{BPI}$, standard-labeled tapes with EBCDIC characters. Requests should be addressed to:

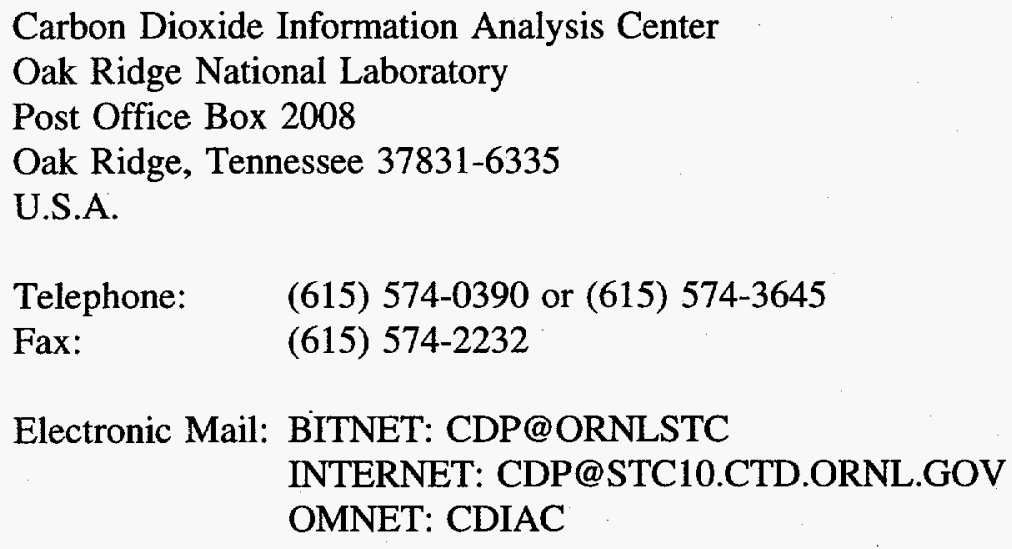

The data files can be also acquired from CDIAC's anonymous FTP account via Internet:

- FTP to cdiac.esd.ornl.gov (128.219.24.36)

- Enter "ftp" or "anonymous" as the userid

- Enter your electronic mail address as the password (e.g.,"alex@alex.esd.ornl.gov")

- Change to the directory "/pub/ndp045"

- Acquire the files using the FTP "get" or "mget" command

\footnotetext{
${ }^{1}$ Please enter your correct address. This address is used by CDIAC to inform data recipients of data revisions and updates.
} 


\section{REFERENCES}

Bryden, H. L. 1973. New polynomials for thermal expansion, adiabatic temperature gradient and potential temperature of seawater. Deep-Sea Research 20: 401-08.

Chipman, D., T. Takahashi, D. Breger, S. Sutherland. 1992. Investigation of carbon dioxide in the South Atlantic and Northern Weddell Sea Areas (WOCE Sections A-12 and A-21) during the Meteor Expedition 11/5, January-March 1990. Lamont-Doherty Geological Observatory of Columbia University, Palisades, N.Y.

Clark, W. C. 1982. Carbon dioxide review. Clarendon Press and Oxford Press, Oxford, England, and New York.

Fofonoff, N. P. 1980. Computation of potential temperature of seawater for an arbitrary reference pressure. Deep-Sea Research 24: 489-91.

Johnson, K. M., A. E. King, and M. Sirburth. 1985. Coulometric $\mathrm{TCO}_{2}$ analyses for marine studies: An introduction. Marine Chemistry 16: 61-82.

Kester, D. R. 1975. Dissolved gases other than $\mathrm{CO}_{2}$. pp. 497-556. In 2nd Edition, J.P. Riley, G. Skirrow (eds.), Chemical Oceanography. Academic Press, London. Vol.1.

Millero, F. J., C.-T. Chen, A: Bradshaw and K. Schleicher. 1980. A new high-pressure equation of state for seawater. Deep-Sea Research 27: 225-64.

Roether, W., M. Sarnthein, T. J. Müller, W. Nellen und D. Sahrhage. 1990. SÜDATLANTICZIRCUMPOLARSTORM, Reise Nr. 11. 3 October 1989 - 11 März 1990. Meteor-Berichte, Universität Hamburg.

Sievers, H. A., and W. D. Nowlin. 1984. The stratification and water masses at Drake Passage. Journal of Geophysics Research 89: 10489-514.

Takahashi, T., D. Chipman, N. Schechtman, J. Goddard, and R. Wanninkof. 1982. Measurements of the partial pressure of $\mathrm{CO}_{2}$ in discrete water samples during the North Atlantic Expedition, the Transient Tracers of Oceans Project. Technical Report to NSF. Lamont-Doherty Earth Observatory, Palisades, N.Y.

U.S. WOCE Implementation Plan. 1991. U.S. Implementation Report No. 1, U.S. WOCE Office, College Station, Tex.

Williams, P. J. 1990. Oceans carbon, and climate change. Scientific Committee on Oceanic Research (SCOR), Halifax, Canada. 

PART 2

CONTENT AND FORMAT OF DATA FILES 



\section{FILE DESCRIPTIONS}

This section describes the content and format of each of the seven files that comprise this NDP (Table 1). Because CDIAC distributes the data set in several ways (e.g., via anonymous FTP and on 9-track magnetic tape), each of the seven files is referenced by both an ASCII file name, which is given in lower-case, bold-faced type (e.g., readme) and a file number. The files and their contents include the following:

readme (File 1), a detailed description of the cruise network, the three FORTRAN 77 data retrieval routines, and the three oceanographic data files;

stainv.for (File 2), a FORTRAN 77 data retrieval routine to read and print m115sta.inv (File 4);

m115dat.for (File 3), a FORTRAN 77 data retrieval routine to read and print m115.dat (File 5);

m115sta.inv (File 4), a listing of the station locations, sampling dates, and sounding bottom depths for each of the 78 stations;

$\square$ m115.dat (File 5), a listing of hydrographic, carbon dioxide, and chemical data for all stations occupied during the R/V Meteor Cruise 11/5;

girarbot.for (File 6), a FORTRAN 77 data retrieval routine to read and print m115gir.dat (File 7);

m115gir.dat (File 7), a listing of total $\mathrm{CO}_{2}$ and hydrographic data sampled from Girard barrels during the R/V Meteor Cruise 11/5.

The remainder of this section describes (or lists, where appropriate) the contents of each of the seven files. The files are discussed in the order in which they appear on the magnetic tape. 
Table 1. Content, size, and format of data files

File number, name, and description
Logical

records
File size

in bytes
Block

size

Record

length

1. readme:

856

48,004

8,000

80

a detailed description

of the cruise network, the

three FORTRAN 77 data

retrieval routines, and the

three oceanographic data

files

2. stainv.for:

29

1,106

8,000

80

a FORTRAN 77 data retrieval

routine to read and print

m115sta.inv (File 4)

3. m115dat.for:

44

1,853

8,000

80

a FORTRAN 77 data retrieval

routine to read and print

m115.dat (File 5)

4. m115sta.inv:

78

3,276

4,100

41

a listing of the station locations, sampling dates, and sounding bottom depths for each of the 78 stations

5. m115.dat:

a listing of hydrographic, carbon dioxide, and chemical data for all stations.

6. girarbot.for:

a FORTRAN 77 data retrieval

routine to read and print

m115gir.dat (File 7)

7. m115gir.dat:

a listing of total $\mathrm{CO}_{2}$ and hydrographic

data sampled from the Girard barrels

Total

$3,303 \quad 396,464$ 


\section{readme (File 1)}

This file contains a detailed description of the data set, the three FORTRAN 77 data retrieval routines, and the three oceanographic data files. It exists primarily for the benefit of individuals who acquire the data files from CDIAC's anonymous FTP area.

\section{stainv.for (File 2)}

This file contains a FORTRAN 77 data retrieval routine to read and print m115sta.inv (File 4). The following is a listing of this program. For additional information regarding variable definitions, variable lengths, variable types, units, and codes, please see the description for m115sta.inv file on pages 24-25.

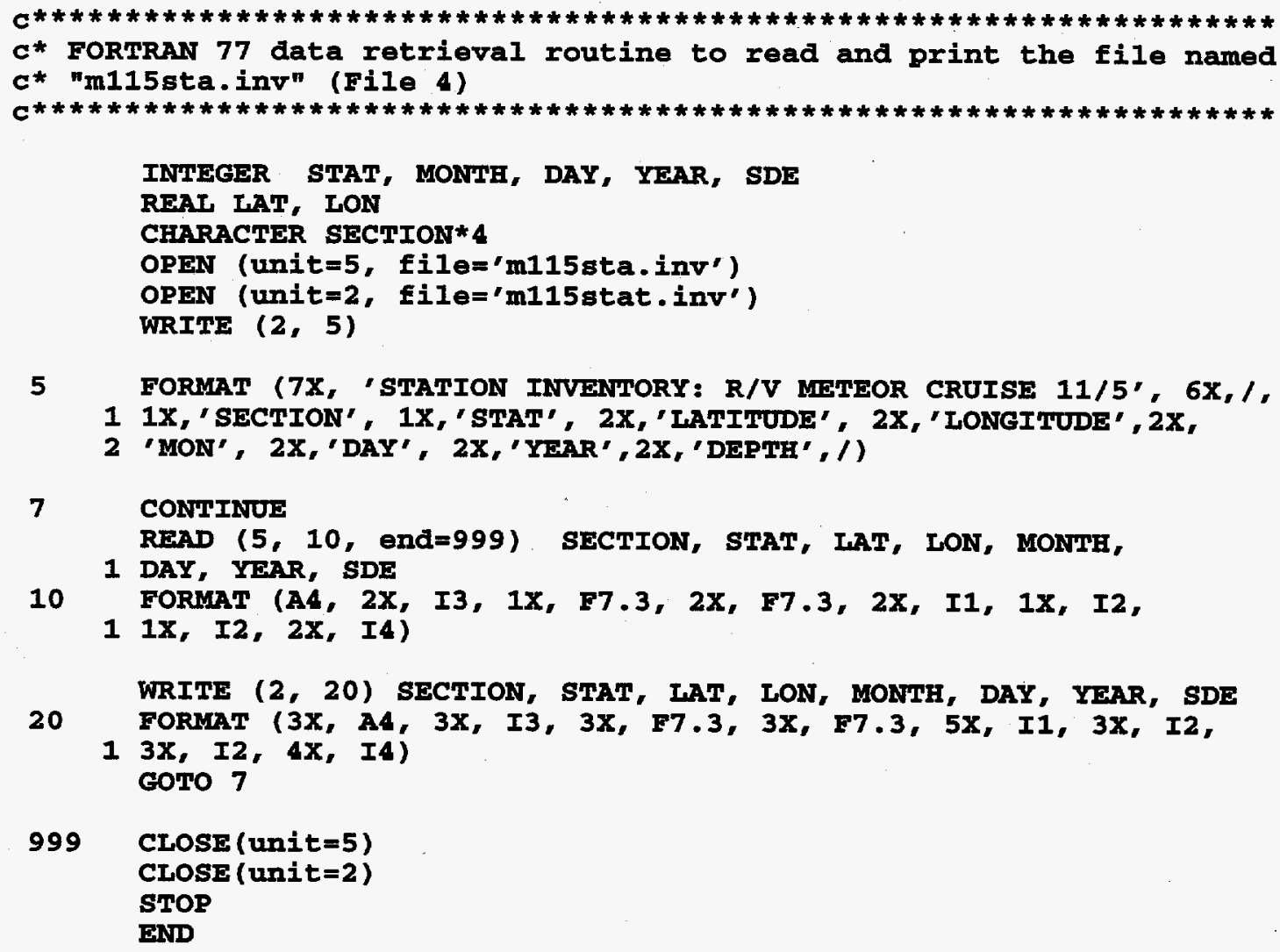




\section{m115dat.for (File 3)}

This file contains a FORTRAN 77 data retrieval routine to read and print m115.dat (File 5). The following is a listing of this program. For additional information regarding variable definitions, variable lengths, variable types, units, and codes, please see the description for m115.dat file on pages 26-28.

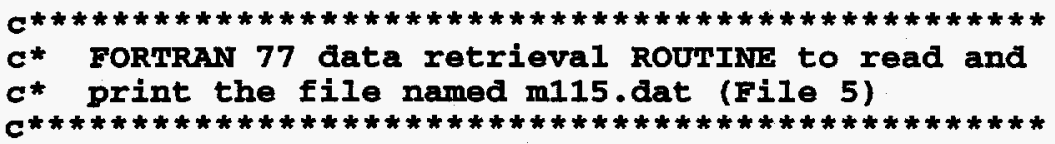

READ (5, 10, end=999) STAT, CAST, SAMP, BOTTLE, CTDPRS, CTDTMP,

1 CTDSAL, THETA, BTLSAL, OXYGEN, SILICA, NITRAT, NITRIT, PHSPHT,

2 TCO2, PCO2, PCO2TEMP, SIGMAO, FIAG

\section{m115sta.inv (File 4)}

This file provides station inventory information for each of the 78 stations occupied during the $\mathrm{R} / \mathrm{V}$ Meteor Cruise 11/5. There is one entry for each station; consequently, the file has 78 
lines. Each line contains a section number, station number, latitude, longitude, sampling date, and sounding depth. The file is sorted by station number and can be read by using the following FORTRAN 77 code (contained in stainv.for, which is File 2):

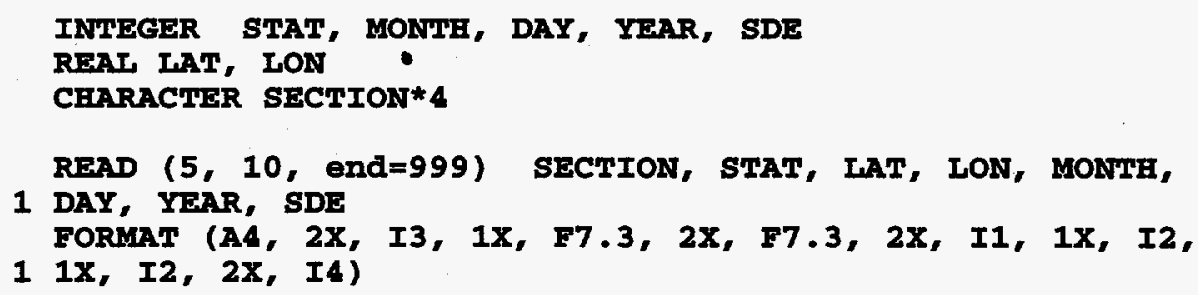

Stated in tabular form, the contents include the following:

\begin{tabular}{llccc}
\hline Variable & $\begin{array}{l}\text { Variable } \\
\text { type }\end{array}$ & $\begin{array}{c}\text { Variable } \\
\text { width }\end{array}$ & $\begin{array}{c}\text { Starting } \\
\text { column }\end{array}$ & $\begin{array}{c}\text { Ending } \\
\text { column }\end{array}$ \\
\hline SECTION & Character & 4 & 1 & 4 \\
STAT & Numeric & 3 & 7 & 9 \\
LAT & Numeric & 7 & 11 & 17 \\
LON & Numeric & 7 & 20 & 26 \\
MONTH & Numeric & 1 & 29 & 29 \\
DAY & Numeric & 2 & 31 & 32 \\
YEAR & Numeric & 2 & 34 & 35 \\
SDE & Numeric & 4 & 38 & 41 \\
\hline
\end{tabular}

where

SECTION is the WOCE section number;

STAT is the station number (values range from 102 to 179);

LAT is the latitude of the station (in decimal degrees);

LON is the longitude of the station (in decimal degrees);

MONTH is the month the station was sampled;

DAY is the day the station was sampled;

YEAR is the year the station was sampled;

SDE is the sounding depth of the station (in meters). 


\section{m115.dat (File 5)}

This file provides hydrographic, carbon dioxide, and chemical data for the 78 stations occupied during the R/V Meteor Cruise 11/5. Each line consists of a station number, cast number, sample number, bottle number, CTD pressure, CTD temperature, CTD salinity, potential temperature, bottle salinity; concentrations of oxygen, silicate, nitrate, nitrite, phosphate, and total carbon; $\mathrm{pCO}_{2} ; \mathrm{pCO}_{2}$ temperature; potential density; and data quality flags. The file is sorted by station number and pressure and can be read by using the following FORTRAN 77 code (contained in m115dat.for, which is File 3):

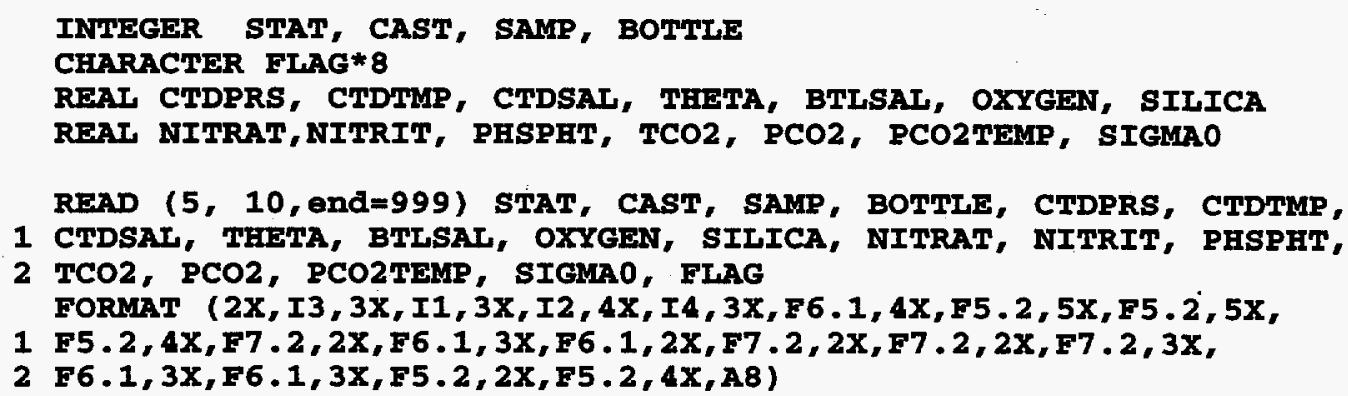

Stated in tabular form, the contents include the following:

\begin{tabular}{llccc}
\hline Variable & $\begin{array}{c}\text { Variable } \\
\text { type }\end{array}$ & $\begin{array}{c}\text { Variable } \\
\text { width }\end{array}$ & $\begin{array}{c}\text { Starting } \\
\text { column }\end{array}$ & $\begin{array}{c}\text { Ending } \\
\text { column }\end{array}$ \\
\hline & Numeric & 3 & 3 & 5 \\
STAT & Numeric & 1 & 9 & 9 \\
CAST & Numeric & 2 & 13 & 14 \\
SAMP & Numeric & 4 & 19 & 22 \\
BOTTLE & Numeric & 6 & 26 & 31 \\
CTDPRS & Numeric & 5 & 36 & 40 \\
CTDTMP & Numeric & 5 & 46 & 50 \\
CTDSAL & Numeric & 5 & 56 & 60 \\
THETA & Numeric & 7 & 65 & 71 \\
BTLSAL & Numeric & 6 & 74 & 79 \\
OXYGEN & Numeric & 6 & 83 & 97 \\
SILICA & Numeric & 7 & 91 & 106 \\
NITRAT & Numeric & 7 & 100 & 115 \\
NITRIT & Numeric & 7 & 109 & 124 \\
PHSPHT & Numeric & 6 & 119 & 133 \\
TCO2 & Numeric & 6 & 128 & 141 \\
PCO2 & Numeric & 5 & 137 & 148 \\
PCO2TEMP & Numeric & 5 & 144 & 160 \\
SIGMA0 & Character & 8 & 153 & \\
FLAG & & & & \\
& & & & \\
\hline
\end{tabular}


where

STAT is the station number (values from 102 to 179);

CAST is the cast number;

SAMP is the sample number;

BOTTLE $^{*} \quad$ is the bottle number;

CTDPRS is the CTD pressure (in dbar);

CTDTMP is the CTD temperature (in ${ }^{\circ} \mathrm{C}$ );

CTDSAL $^{*}$ is the CTD salinity [in Practical Salinity Units (PSU)];

THETA is the potential temperature (in ${ }^{\circ} \mathrm{C}$ );

BTLSAL $^{*}$ is the salinity (in PSU);

OXYGEN $^{*} \quad$ is the oxygen concentration (in $\mu \mathrm{mol} / \mathrm{kg}$ );

SILICA $^{*} \quad$ is the silicate concentration (in $\mu \mathrm{mol} / \mathrm{kg}$ );

NITRAT $^{*} \quad$ is the nitrate concentration (in $\mu \mathrm{mol} / \mathrm{kg}$ );

NITRIT $^{*} \quad$ is the nitrite concentration (in $\mu \mathrm{mol} / \mathrm{kg}$ );

PHSPHT $^{*} \quad$ is the phosphate concentration (in $\mu \mathrm{mol} / \mathrm{kg}$ );

$\mathrm{TCO} 2$ is the total carbon concentration (in $\mu \mathrm{mol} / \mathrm{kg}$ );

$\mathrm{PCO} 2$ is the partial pressure of $\mathrm{CO}_{2}$ (in $\mu$ atm and measured at $20^{\circ} \mathrm{C}$ );

PCO2TEMP is the temperature of the $\mathrm{pCO}_{2}$ samples (in ${ }^{\circ} \mathrm{C}$ );

SIGMA0 is the potential density (in sigma units at $0 \mathrm{dbar}$ );

FLAG is an 8-digit character variable that contains data quality flag codes for parameters flagged by an asterisk ( $\left(^{*}\right)$ :

Quality flags definitions:

1 = Sample for this measurement was drawn from water bottle but analysis was not received;

2 = Acceptable measurement;

3 = Questionable measurement;

4 = Bad measurement;

5 = Not reported; 
6 = Mean of replicate measurements;

7 = Manual chromatographic peak measurement;

8 = Irregular digital chromatographic peak integration;

9 = Sample not drawn for this measurement from this bottle.

\section{girarbot.for (File 6)}

This file contains a FORTRAN 77 data retrieval routine to read and print m115gir.dat (File 7). The following is a listing of this program. For additional information regarding variable definitions, variable lengths, variable types, units, and codes, please see the description for m115gir.dat file on pages $28-29$.

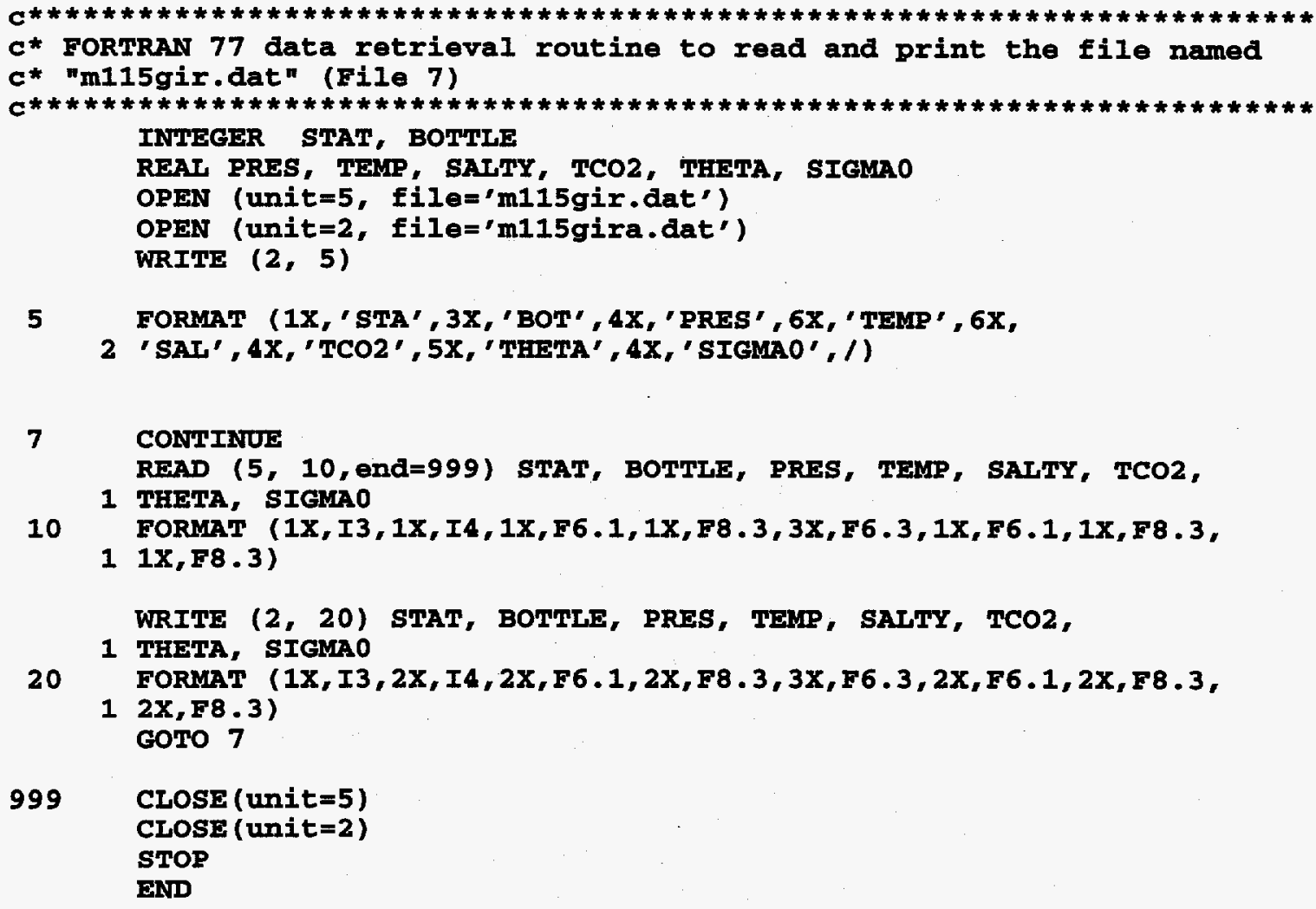

\section{m115gir.dat (File 7)}

This file provides the hydrographic and total $\mathrm{CO}_{2}$ data sampled from Girard barrels during $\mathrm{R} / \mathrm{V}$ Meteor Cruise 11/5. Each line consists of a station number, girard bottle number, pressure (depth), temperature, salinity, total $\mathrm{CO}_{2}$, potential temperature, and potential density. The file is sorted by station number and pressure and can be read by using the following FORTRAN 77 code (contained in girarbot.for, which is File 6): 


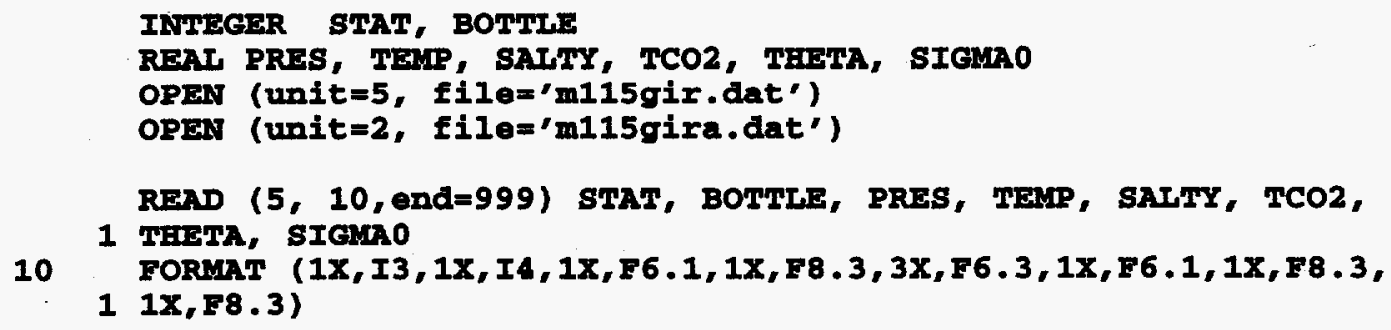

Stated in tabular form, the contents include the following:

\begin{tabular}{llccc}
\hline Variable & $\begin{array}{c}\text { Variable } \\
\text { type }\end{array}$ & $\begin{array}{c}\text { Variable } \\
\text { width }\end{array}$ & $\begin{array}{c}\text { Starting } \\
\text { column }\end{array}$ & $\begin{array}{c}\text { Ending } \\
\text { column }\end{array}$ \\
\hline STAT & Numeric & 3 & 2 & 4 \\
BOTTLE & Numeric & 4 & 7 & 10 \\
PRES & Numeric & 6 & 13 & 18 \\
TEMP & Numeric & 8 & 21 & 28 \\
SALTY & Numeric & 6 & 32 & 37 \\
TCO2 & Numeric & 6 & 40 & 45 \\
THETA & Numeric & 8 & 48 & 55 \\
SIGMA0 & Numeric & 8 & 58 & 65 \\
\hline
\end{tabular}

where

STAT is the station number (values range from 102 to 179);

BOTTLE is the girard bottle number;

PRES is the CTD pressure (in dbar);

TEMP is the CTD temperature (in ${ }^{\circ} \mathrm{C}$ );

SALTY is the bottle salinity (in PSU);

$\mathrm{TCO} 2$ is the total carbon concentration (in $\mu \mathrm{mol} / \mathrm{kg}$ );

THETA is the potential temperature (in ${ }^{\circ} \mathrm{C}$ );

SIGMA0 is the potential density (in sigma units at $0 \mathrm{dbar}$ ). 



\section{VERIFICATION OF DATA TRANSPORT}

The data files contained in this Numeric Data Package can be read by using the FORTRAN 77 data retrieval programs provided. Users should visually examine each data file to verify that the data were correctly transported to their systems. To facilitate the visual inspection process, partial listings of each data file are provided in Tables 2-4. Each of these tables contains the first and last five lines of a data file. 
Table 2. Partial listing of "m115sta.inv"

(File 4)

First five lines of the file:

$\begin{array}{lllllllr}A-21 & 102 & -56.330 & -67.995 & 1 & 24 & 90 & 103 \\ A-21 & 103 & -56.917 & -68.250 & 1 & 24 & 90 & 3090 \\ A-21 & 104 & -57.330 & -68.250 & 1 & 24 & 90 & 4390 \\ A-21 & 105 & -57.835 & -68.242 & 1 & 25 & 90 & 3757 \\ A-21 & 106 & -58.335 & -68.238 & 1 & 26 & 90 & 3855\end{array}$

Last five lines of the file:

$\begin{array}{llllllll}\mathrm{A}-12 & 175 & -37.537 & 14.352 & 3 & 4 & 90 & 4963 \\ \mathrm{~A}-12 & 176 & -36.997 & 15.385 & 3 & 5 & 90 & 4804 \\ \mathrm{~A}-12 & 177 & -36.447 & 16.413 & 3 & 5 & 90 & 4506 \\ \mathrm{~A}-12 & 178 & -35.870 & 17.453 & 3 & 6 & 90 & 3891 \\ \mathrm{~A}-12 & 179 & -35.332 & 18.450 & 3 & 6 & 90 & 1794\end{array}$


Table 3. Partial listing of "m115.dat"

(File 5)

First five lines of the file:

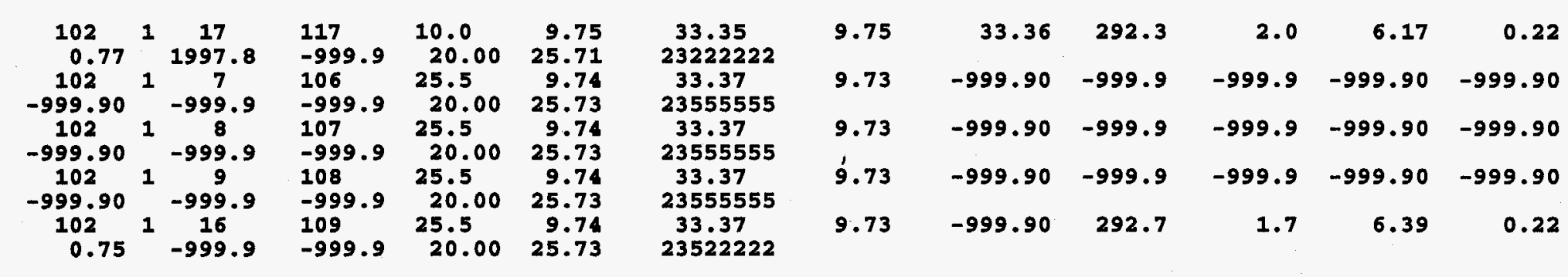

Last five lines of the file:

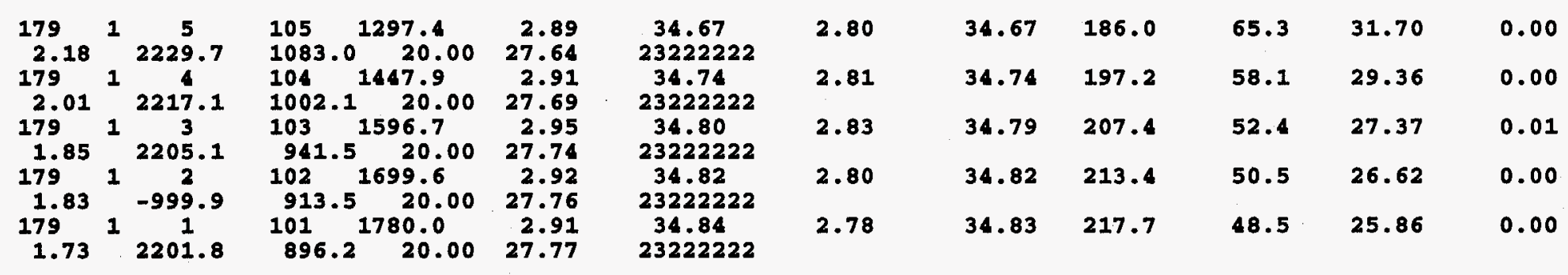


Table 4. Partial listing of "m115gir.dat"

(File 7)

First five lines of the file:

$\begin{array}{rrrrrrrrr}104 & 9310 & 14.1 & -999.900 & 34.005 & 2060.9 & -999.900 & -999.900 \\ 104 & 9317 & 54.5 & 8.133 & 34.025 & 2068.6 & 8.128 & 26.489 \\ 104 & 9306 & 105.0 & -999.900 & 34.056 & 2100.9 & -999.900 & -999.900 \\ 104 & 9302 & 255.6 & -999.900 & 34.186 & 2113.4 & -999.900 & -999.900 \\ 104 & 9303 & 507.5 & -999.900 & 34.211 & 2120.7 & -999.900 & -999.900\end{array}$

Last five lines of the file:

$\begin{array}{llllllll}172 & 9417 & 4072.3 & 1.477 & 34.770 & 2236.6 & 1.150 & 27.850 \\ 172 & 9404 & 4792.1 & 1.124 & 34.734 & 2248.3 & 0.727 & 27.849 \\ 172 & 9401 & 5018.9 & 1.075 & 34.728 & 2250.1 & 0.653 & 27.849 \\ 173 & 9306 & 3278.9 & 2.172 & 34.836 & 2213.1 & 1.911 & 27.847 \\ 173 & 9303 & 3299.3 & 2.151 & 34.835 & 2215.0 & 1.889 & 27.848\end{array}$


APPENDIX A STATION INVENTORY 



\section{APPENDIX A STATION INVENTORY}

This appendix lists station inventory information for the 78 sites occupied during the R/V Meteor Cruise 11/5 in the South Atlantic Ocean and Northern Weddell Sea. The meanings of the column headings in Table A-1 are as follows.

SECTION is the WOCE section number;

STAT is the station number;

LATITUDE is the latitude of the station (in decimal degrees). Stations in the Southern Hemisphere have negative latitudes;

LONGITUDE is the longitude of the station (in decimal degrees). Stations in the Western Hemisphere have negative longitudes;

MON is the month the station was sampled;

DAY is the day the station was sampled;

YEAR is the year the station was sampled;

DEPTH is the sounding bottom depth of each station (in meters). 
Table A.1 Station inventory information for the 78 sites occupied during the R/V Meteor Cruise 11/5.

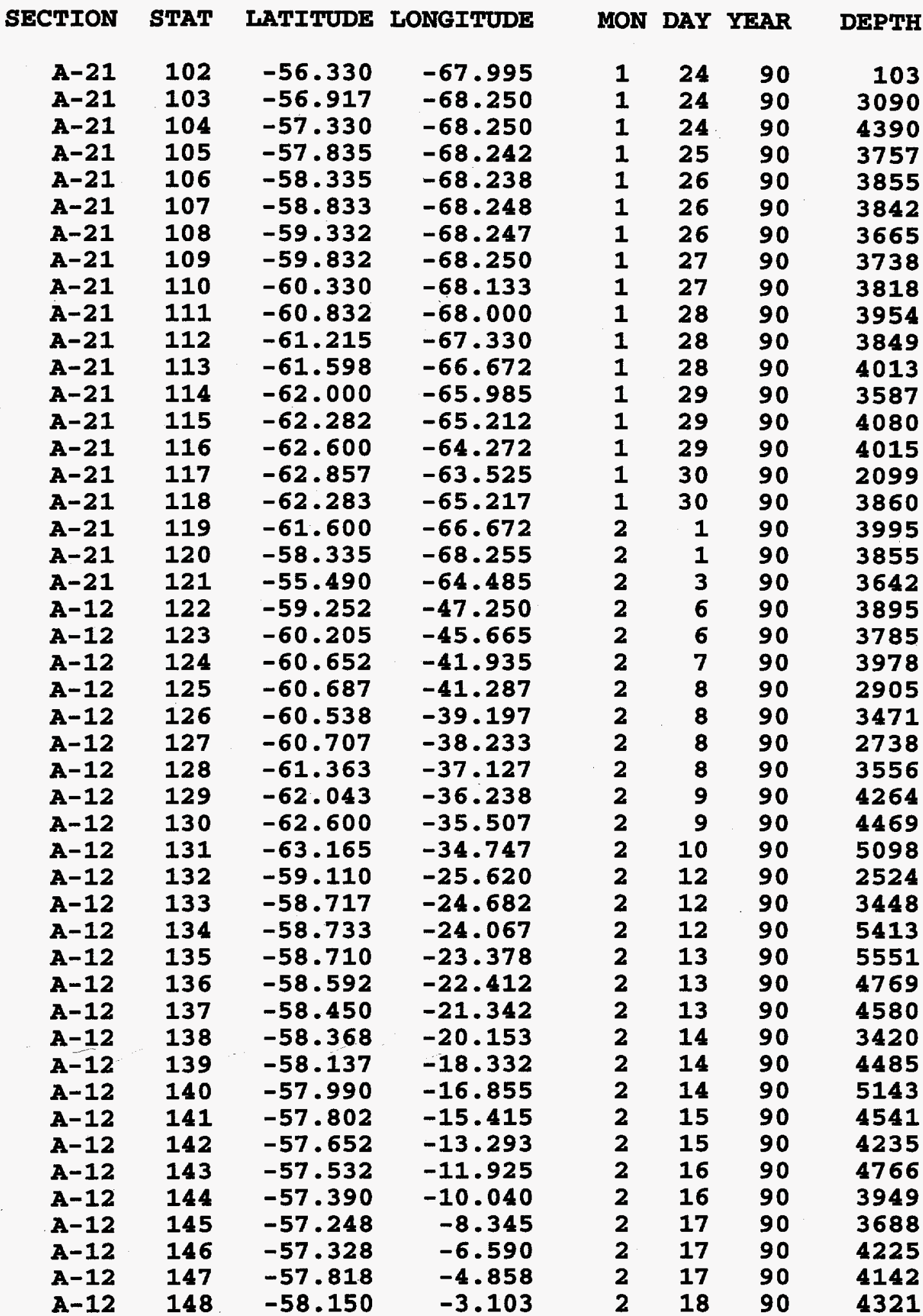


Table A.1 (continued)

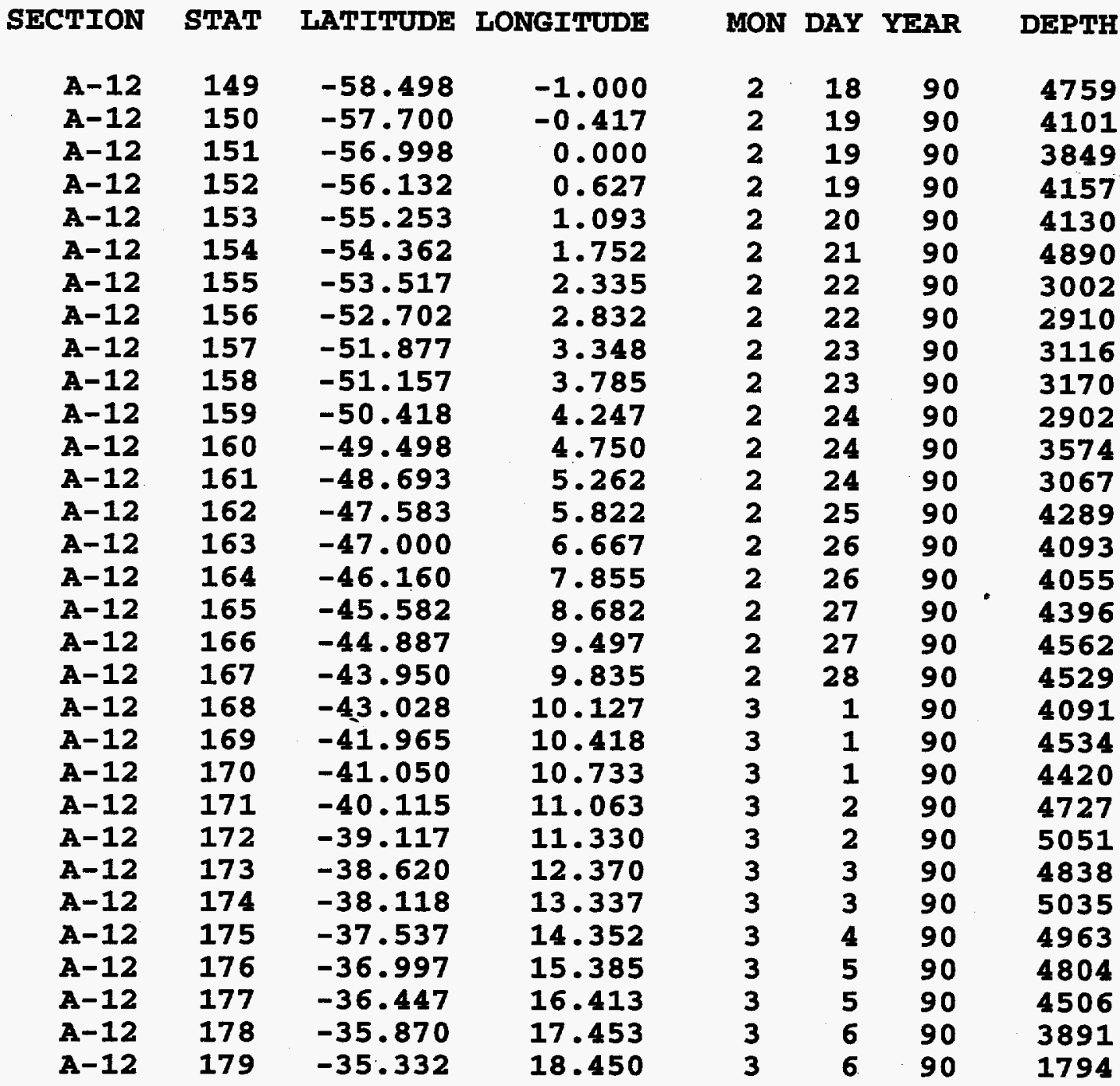


APPENDIX B

SURFACE WATER DATA 


\section{APPENDIX B SURFACE WATER DATA}

This appendix lists surface water data collected during the R/V Meteor Cruise 11/5. The meanings of the column headings in table B-1 are as follows.

Sta

Date

Lat

Long

Temp

Sal

Seawater $\mathrm{pCO}_{2}$ in situ

Seawater $\mathrm{pCO}_{2} 20^{\circ} \mathrm{C}$

Atmosphere $\mathrm{VCO}_{2}$

Atmosphere $\mathrm{pCO}_{2}$

Delta $\mathrm{pCO}_{2}$ is the sea-air $\mathrm{pCO}_{2}$ difference (in $\mu \mathrm{atm}$ );

$\mathrm{TCO}_{2}$

$\mathrm{O}_{2}$

$\mathbf{P O}_{4}$

$\mathrm{NO}_{3}$

$\mathrm{SiO}_{3}$

TALK

PALK

is the station number;

is the surface water salinity (in PSU); $\mathrm{VCO}_{2}$ (air);

is the nitrate concentration (in $\mu \mathrm{mol} / \mathrm{kg}$ ); salinity, and nutrient data; is the date (month, day, and year) the station was sampled;

is the latitude of the station (in degrees and minutes);

is the longitude of the station (in degrees and minutes);

is the surface water temperature $\left(\right.$ in ${ }^{\circ} \mathrm{C}$ );

is the partial pressure of $\mathrm{CO}_{2}$ measured at in situ temperature (in $\mu \mathrm{atm}$ );

is the partial pressure of $\mathrm{CO}_{2}$ measured at $20^{\circ} \mathrm{C}$ (in $\mu$ atm);

is the atmospheric $\mathrm{CO}_{2}$ concentration (in $\mathrm{ppm}$ );

is the atmosphere partial pressure of $\mathrm{CO}_{2}$ (in $\mu \mathrm{atm}$ ), calculated from $\mathrm{VCO}_{2}$ of dry air at $100 \%$ relative humidity by using $350.0 \mathrm{ppm}$ as the mean value of

is the total carbon concentration (in $\mu \mathrm{mol} / \mathrm{kg}$ );

is the oxygen concentration (in $\mu \mathrm{mol} / \mathrm{kg}$ );

is the phosphate concentration (in $\mu \mathrm{mol} / \mathrm{kg}$ );

is the silicate concentration (in $\mu \mathrm{mol} / \mathrm{kg}$ );

is the total alkalinity (in $\mu \mathrm{EQ} / \mathrm{kg}$ ), computed by using the total $\mathrm{CO}_{2}, \mathrm{pCO}_{2}$,

is the potential alkalinity (in $\mu \mathrm{EQ} / \mathrm{kg}$ ), defined by Total Alkalinity + Nitrate. 
Table B.1 Surface water data obtained during the R/V Meteor Cruise 11/5 [reprinted from Chipman et al. (1992)]

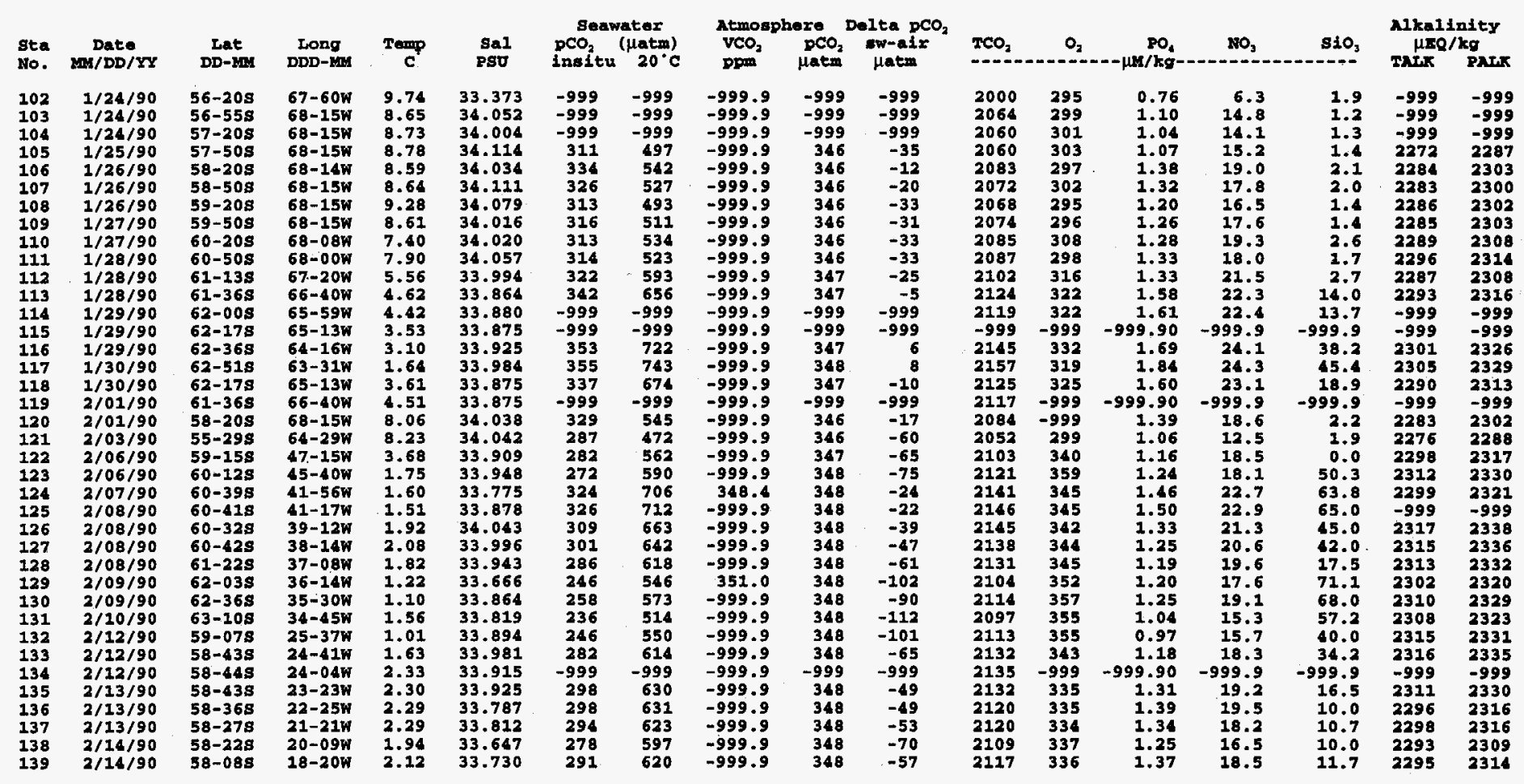


Table B.1 (continued)

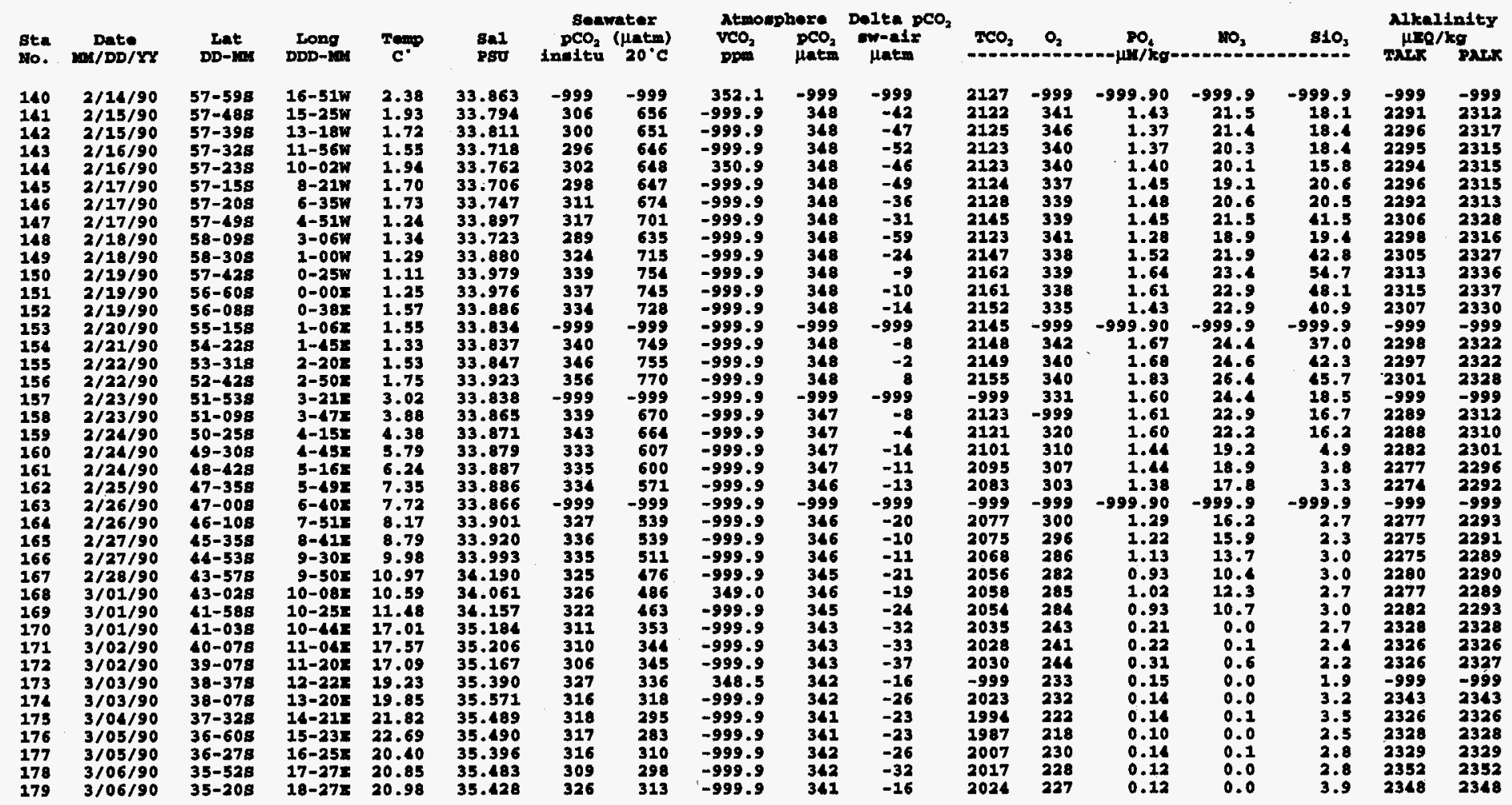




\section{INTERNAL DISTRIBUTION}

1. L. D. Bates

2. B. A. Berven

3. T. A. Boden

4. J. B. Cannon

5. J. H. Cushman

6. R. M. Cushman

7. V. H. Dale

8. M. P. Farrell

9. D. E. Fowler

10. C. W. Gehrs

11. S. G. Hildebrand

12. P. Kanciruk

13. D. Kaiser

14. A. Kozyr

15. T. H. Peng

16. D. E. Reichle

17. F. E. Sharples

18. D. S. Shriner

19. S. H. Stow

20-219. CDIAC

220. Central Research Library

221-222. ESD Library

223-224. Laboratory Records Department

225. Laboratory Records, RC

226. ORNL Patent Office

227. ORNL Y-12 Technical Library

\section{EXTERNAL DISTRIBUTION}

228. S. S. Alexander, Pennsylvania State University, Department of Geosciences, 503 Deike Building, University Park, PA 16802

229. J. H. Allen, National Oceanic and Atmospheric Administration, National Geophysical Data Center Code E/GC2, 325 Broadway, Boulder, CO 80303

230. D. Alvic, EERC/UT, Pellissippi Office, Ste. 100, 10521 Research Drive, Knoxville, TN 37932

231. R. C. Barry, University of Colorado, World Data Center A, Glaciology, CIRES, Campus Box 449, Boulder, CO 80309-0449 
232. Linda S. Bingler, Pacific Northwest Laboratories, Marine Sciences Laboratory, 1529 West Sequim Bay Road, Sequim, Washington 98382

233-237. Dee Breger, Lamont-Doherty Earth Observatory of Columbia University, Climate/Environment/Ocean Division, RT 9W, Palisades, NY 10964-8000

238. M. A. Chinnery, National Oceanic and Atmospheric Administration, National Geophysical Data Center Code E/GC2, 325 Broadway, Boulder, CO 80303

239-243. David W. Chipman, Lamont-Doherty Earth Observatory of Columbia University, Climate/Environment/Ocean Division, RT 9W, Palisades, NY 10964-8000

244. Roger C. Dahlman, Global Change Research Program, Environmental Sciences Division, Office of Health and Environmental Research, ER-74, U.S. Department of Energy, Washington, DC 20585

245. Andrew G. Dickson, University of California, Marine Physical Laboratory-0902 9500 Gilman Drive, La Jolla, CA 92093-0902

246. W. Draeger, EROS Data Center, U.S. Geological Survey, Sioux Falls, SD 57198

247. M. Dryer, National Oceanic and Atmospheric Administration, Space Environmental Lab., ERL/OAR, R/E/SE, 320 Broadway, Boulder, CO 80303

248. J. F. Farvolden, Professor, Department of Earth Sciences, University of Waterloo, Waterloo, Ontario N2L 3G1 Canada

249. Richard Feely, National Oceanic \& Atmospheric Administration, pacific Marine Envir. Lab, 7600 Sand Point Way, NE, Seattle, WA 98115

250. J. Filson, National Earthquake Information Center, U.S. Geological Survey, Denver Federal Center, P.O. Box 20546, Denver, CO 80225

251. Jerry F. Franklin, Bloedel Professor of Ecosystem Analysis, College of Forest Resources, University of Washington, Anderson Hall (AR-10), Seattle, WA 98195

252. Dr. Diana W. Freckman, Director, College of Natural Resources, 101 Natural Resources Building, Colorado State University, Fort Collins, CO 80523

253. Catherine Goyet, Chemistry Dept., Woods Hole Oceanographic Institution, Clark 461, Woods Hole, MA 02543

254. S. Graves, National Aeronautics and Space Administration Headquarters Code SED, 600 Independence Avenue, Washington, DC 20546

255. J. L. Green, National Space Science Data Center, NASA Goddard Space Flight Center, Code 630.2, Greenbelt, MD 20771 
256. K. D. Hadeen, National Oceanic and Atmospheric Administration, NESDIS/NCDC, Federal Building MC E/CC, Asheville, NC 28801

257. R. C. Harriss, Institute for the Study of Earth, Oceans, and Space, Science and Engineering Research Building, University of New Hampshire, Durham, NH 03824

258. W. J. Hinze, Purdue University, Department of Earth and Atmospheric Sciences, West Lafayette, IN 47907

259. G. Y. Jordy, Director, Office of Program Analysis, Office of Energy Research, ER-30, G-226, U.S. Department of Energy, Washington, DC 20585

260. Terrence M. Joyce, WOCE Hydrographic Program Office, Woods Hole Oceanographic Institution, Woods Hole, MA 02543

261. Thomas R. Karl, National Climatic Data Center, Federal Building, 37 Battery Park Avenue, Asheville, NC 28801

262. Charles D. Keeling, Scripps Institution of Oceanography, University of California San Diego, Geological Research Division, A020, 2314 Ritter Hall, La Jolla, CA 920930220

263. Robert Key, Princeton University, Geology Department, Princeton, NY 08544

264. D. Lauer, EROS Data Center, U.S. Geological Survey, Sioux Falls, SD 57198

265. S. Levitus, NOAA/National Oceanographic Data Center, 1825 Connecticut Avenue, NW, Washington, DC 20235

266. A. M. Linn, Program Officer, BESR, National Academy of Sciences, Harris Building 372, 2101 Constitution Avenue NW, Washington, DC 20418

267. M. S. Loughridge, National Oceanic and Atmospheric Administration, National Geophysical Data Center, Code E/GC3, 325 Broadway, Boulder, CO 80303

268. H. M. McCammon, Acting Deputy Director, Environmental Sciences Division, Office of Health and Environmental Research, Office of Energy Research, ER-74, U.S. Department of Energy, Washington; DC 20585

269. Frank J. Millero, University of Miami, RSMAS, 4600 Rickenbacker Causeway, Miami, FL 33149-1098

270. R. H. Olsen, Vice President for Research, University of Michigan, Medical Science Building II, \#5605, 1301 East Catherine Street, Ann Arbor, MI 48109-0620

271. J. T. Overpeck, National Oceanic and Atmospheric Administration, National Geophysical Data Center, Paleoclimatology Program, 325 Broadway E/EC, Boulder, 
$\mathrm{CO} 80303$

272. Ari Patrinos, Acting Director Office of Health and Environmental Research, ER-74, U.S. Department of Energy, Washington, DC 20585

273. Dr. Thomas C. Peterson, national Climatic Data Center, Federal Building, 37 Battery Park Avenue, Asheville, NC 28801

274. S. Ichtiaque Rasool, IGBP Data and Information System Office, Universite Paris, Tour 26, 4 Etage, Aile 26-16, 4 Place Jussieu, 75230 Paris, Cedex 06, France

275. Michael R. Riches, Acting Director, Environmental Sciences Division, Office of Health and Environmental Research, ER-74, U.S. Department of Energy, Washington, DC 20585

276. Wolfgang Roether, Universitaet Bremen, Fachbereich 1, Postfach 3304 40, Bremen 33 W-2800, Germany

277. S. Ruttenberg, Univ. Corporation for Atmospheric Research, CSNET, P. O. Box 3000, Boulder, CO 80307-3000

278. A. L. Shumbera, National Oceanic and Atmospheric Administration, WDC-A for Meteorology, National Climatic Data Center, Federal Building MC E/CC, Asheville, NC 28801

279. Mr. Peter M. Steurer, National Climatic Data Center, Federal Building, 37 Battery Park Avenue, Asheville, NC 28801

280-284. Stewart C. Sutherland, Lamont-Doherty Earth Observatory of Columbia University, Climate/Environment/Ocean Division, RT 9W, Palisades, NY 10964-8000

285. James H. Swift, Scripps Institution of Oceanography, University of California, San Diego Oceanographic Data Facility, 9500 Gilman Drive, La Jolla, CA 92093-0124

286-290. Taro Takahashi, Lamont-Doherty Earth Observatory of Columbia University, Climate/Environment/Ocean Division, RT 9W, Palisades, NY 10964-8000

291. Lynne D. Talley, Scripps Institution of Oceanography, UCSD 0230, 9500 Gilman Drive, La Jolla, CA 92075-0230

292. Douglas W. R. Wallace, Brookhaven National Laboratory, Oceanographic Sciences Division, Bldg. 318, Upton, NY 11973

293. F. Webster, University of Delaware, College of Marine Studies, Lewes, DE 19958

294. Dr. Cort J. Willmott, Chair, Department of Geography, University of Delaware, Newark, DE 19716 
295. Christopher Winn, University of Hawaii, School of Ocean and Earth Science and Technology, 1000 Pope Road, Honolulu, HI 96833

296. F. J. Wobber, Environmental Sciences Division, Office of Health and Environmental Research, Office of Energy Research, ER-74, U.S. Department of Energy, Washington, DC 20585

297. L. W. Wolf, National Research Council, Commission on Geosciences, Environment, and Resources, 2101 Constitution Avenue, Washington, DC 20418

298. Ms. Hengchun Ye, Department of Geography, University of Delaware, Newark, DE 19716

299. Office of Assistant Manager for Energy Research and Development, U.S. Department of Energy Oak Ridge Operations, P. O. Box 2001, Oak Ridge, TN 37831-8600

300-301. Office of Scientific and Technical Information, P. O. Box 62, Oak Ridge, TN 37831 